\title{
Bacterioplankton intra-annual variability: importance of hydrography and competition
}

\author{
Johan Wikner ${ }^{1,2, *}$ Åke Hagström ${ }^{3}$ \\ ${ }^{1}$ Department of Microbiology, Umeå University, 90187 , Umeå, Sweden \\ ${ }^{2}$ Umeå Marine Sciences Centre, Umeå University, Norrbyn, 910 20, Hörnefors, Sweden \\ ${ }^{3}$ Department of Marine Science, Kalmar University, Box 905, 398 29, Kalmar, Sweden
}

\begin{abstract}
Field data from a $1.5 \mathrm{yr}$ intensive study of 1 coastal $(0$ to $20 \mathrm{~m})$ and 2 of fhore stations $(0$ to $100 \mathrm{~m}$ ) in the northern Baltic were analysed. Specific interest was paid to the difference in the spatiotemporal variation of bacterioplankton and its controlling factors. Less than $31 \%$ of the annual bacterial biomass production $\left(P_{\mathrm{b}}\right)$ occurred in the photic zone during the productive season at the offshore stations. This suggested an uncoupling between $P_{\mathrm{b}}$ and phytoplankton carbon fixation, which was further supported by the lack of a significant correlation between these variables in the photic zone. The basin with high allochthonous loading and long residence time showed high $P_{\mathrm{b}}$ relative to autochthonous carbon fixation and low variance of $P_{\mathrm{b}}$ and bacterial abundance $\left(N_{\mathrm{b}}\right)$, suggesting an important contribution of terrestrial dissolved organic carbon to the carbon and energy supply. Bacterial per capita growth rate $\left(r_{c}\right)$ was highest during spring, while $P_{\mathrm{b}}$ was highest during summer at all stations. The seasonal variation in $P_{\mathrm{b}}$ was mainly explained by variation in the $r_{\mathrm{c}}$, rather than in $N_{\mathrm{b}}$. A positive correlation of $N_{b}$ with temperature, and a negative correlation with salinity, suggested tnat $>01 \%$ of the seasonal variation in $N_{b}$ was a consequence of the formation of a stratified photic zone with a higher carrying capacity. Temperature limitation of $r_{\mathrm{C}}$ only occurred in the stratified photic zone, suggesting that other growth factors were sufficient during this period. A density limitation of the maximum $r_{c}$ was observed at all stations during autumn and winter in both depth layers, suggesting competition to be of periodic importance. Bacterioplankton with a low $r$ (intrinsic growth rate) and high $K$ (carrying capacity) strategy dominated when sedimenting particles were a major resource in the aphotic zone, while the opposite strategy dominated during winter at low cell densities, when dissolved substrates were the major resource.
\end{abstract}

KEY WORDS: Estuarine Pelagic - Bacteria - Growth - Abundance - Seasonal - Temperature - Salinity Control $\cdot$ Competition

\section{INTRODUCTION}

Intra-annual temperature control of bacterioplankton biomass and its production has been derived from several field studies based on observed correlations (Findlay et al. 1991, White et al. 1991, Ducklow \& Shiah 1993, Hoch \& Kirchman 1993, Turner \& Borkman 1993). In contrast to this evidence, correlations between phytoplankton carbon fixation and bacterial biomass production are lacking. Neither has a clear relationship between bacterial abundance and chlorophyll a been demonstrated. The lack of a clear correla-

•E-mail: johan.wikner@micro.umu.se tion between bacterial and phytoplankton variables within studied ecosystems is in contrast to, but does not contradict, the observation that these variables correlate in inter-ecosystem comparisons (Cole et al. 1988, White et al. 1991). However, it suggests that phytoplankton production and biomass may not be directly responsible for controlling bacterioplankton variability on the intra-annual and intra-ecosystem scale. This may be especially important in estuarine ecosystems, where supply of allochthonous dissolved organic carbon (DOC) may uncouple bacterial biomass productivity from phytoplankton carbon fixation. Lower spatiotemporal association between bacterial variables and phytoplankton carbon fixation on the seasonal 


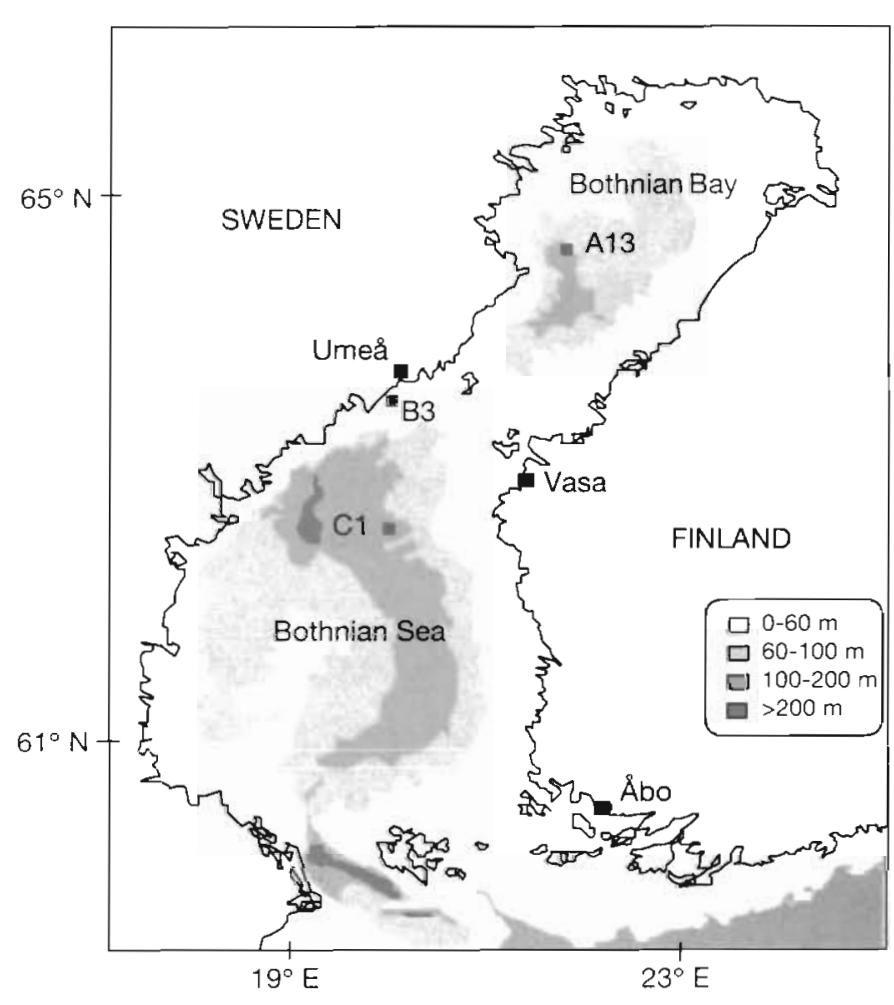

Fig. 1. Sampling stations in the Gulf of Bothnia, northern Baltic. Station specifications are given in the 'Methods'

scale would thus be expected where allochthonous DOC is an important source of materials and energy.

In view of the importance of bacterioplankton in the Carbon cycle (Cole et al. 1988, Hagström et al. 1988), interpretation of natural patterns should constitute an important step towards an understanding of the control of bacterioplankton. Studies on the ecosystem level in this context have the advantage of including the multitude of trophic interactions and controlling factors occurring in natural environments (Pace 1998). Patterns from ecosystem studies may indicate factors of importance for the control of bacterioplankton at the seasonal scale. At the same time the complexity of natural environments imposes careful interpretation as different environmental factors may be indirectly correlated, without a causal relationship. Associations may further be limited to certain seasons or environmental conditions and thus obscured in data sets aggregated on larger scales.

A first step towards an understanding of the control of bacterial biomass production $\left(P_{\mathrm{b}}\right)$ is to seek associations between the intrinsic rate of increase of each bacterial cell (i.e. bacterial specific growth rate), $r_{b}$, and the bacterial density, $N_{b}$, and potential controlling factors in field data sets. $P_{\mathrm{b}}$ is according to ecological theory (Begon et al. 1988) the product of $r_{b}$ and $N_{b}$ by the equation:

$$
P_{\mathrm{b}}=r_{\mathrm{b}} \times N_{\mathrm{b}}
$$

The control of $P_{b}$ is expected to be a combination of factors affecting either $r_{\mathrm{b}}$ or $N_{\mathrm{b}}$. Limitation of substrate or temperature would primarily affect $r_{\mathrm{b}}$, while, for example, predator or parasite activity, via its effect on $N_{\mathrm{b}}$, also would influence the control of $P_{\mathrm{b}}$ (Thingstad \& Sakshaug 1990).

Evidence for the occurrence of resource competition in natural waters has been inferred from inter-ecosystem comparisons (Billen et al. 1990), but has not been extensively elucidated on the intra-annual scale in the current literature. Other biological factors that may control the intra-annual variation in bacterial abundance include bacterivores, who may annually graze the bacterioplankton production (Wikner \& Hagström 1991), and bacteriophages (Proctor \& Fuhrman 1990). The relative importance of bacterivores and bacteriophages for the intra-annual variation in bacterial abundance is, however, unclear and is expected to vary with season (Psenner \& Sommaruga 1992).

In this study a field data set covering $18 \mathrm{mo}$ and 0 to $100 \mathrm{~m}$ depths from 3 sites with different water exchange and freshwater discharge was investigated. We hypothesised that an environment with a high supply of allochthonous DOC and long residence time would show lower seasonal variability and clearer decoupling from phytoplankton if allochthonous DOC was a carbon and energy source of importance. Natural patterns of bacterial community biomass productivity and abundance were further analysed with the aim of finding controlling factors. Samples were compared on the scale of individual sampling bottles (i.e. 5 I scale). We present different associations suggesting controlling or limiting factors for the bacterial intrinsic rate of growth and abundance.

\section{METHODS}

Stations and hydrographic measurements. The sampled stations were located in Bothnian Bay (northern basin, $64^{\circ} 42.50^{\prime} \mathrm{N}, 22^{\circ} 04.00^{\prime} \mathrm{E}_{\mathrm{i}}$ Stn A13, Helsinki Commission standard nomenclature), the Bothnian Sea (southern basin, 620 35.20' N, 19 $9^{\circ} 58.32^{\prime} E_{i}$ Stn. C1) and the Ore estuary (northern Bothnian Sea, 63 $30.50^{\prime}$ N, $19^{\circ} 48.00^{\prime} E_{i}$ Stn B3) (Fig. 1). The sites differ in morphometric, hydrographic and geochemical characteristics (Wulff \& Rahm 1990). The Bothnian Bay has double the river supply of DOC and a longer residence time than the Bothnian Sea (Table 1). The Ore estuary has a more than 10-fold higher supply of riverine DOC, but a much shorter residence time, primarily through exchange with the main basin of the Bothnian Sea (Forsgren \& Jansson 1993). 
Table 1. Morphometric and hydrographic characteristics of the sampling sites. $D_{\text {ave }}$ : mean depth of the basins; $V$ : the volume of the basins; $Q_{\mathrm{tw}}$ : the annual freshwater discharge; $T_{R}$ : the residence time of the basins; $Q_{D O C}$ : the annual DOC discharge (for a water column of mean depth). Morphometric and freshwater discharge values are from HELCOM (1990) and Forsgren \& Jansson (1992). Discharge of DOC is based on data from Pettersson (1992)

\begin{tabular}{|lccccc|}
\hline Location & $\begin{array}{c}D_{\text {ave }} \\
(\mathrm{m})\end{array}$ & $\begin{array}{c}V \\
\left(\mathrm{~km}^{3}\right)\end{array}$ & $\begin{array}{c}Q_{\mathrm{fw}} \\
\left(\mathrm{km}^{3} \mathrm{yr}^{-1}\right)\end{array}$ & $\begin{array}{c}T_{R} \\
(\mathrm{yr})\end{array}$ & $\begin{array}{c}Q_{\mathrm{Doc}} \\
\left(\mathrm{mmol} \mathrm{C} \mathrm{dm}^{-2} \mathrm{yr}^{-1}\right)\end{array}$ \\
\hline Bothnian Bay & 43 & 1481 & 104 & 5.3 & 18 \\
Ore estuary & 16 & 1.0 & 1.2 & 0.027 & 208 \\
Bothnian Sea & 68 & 4308 & 105 & 2.8 & 7.7 \\
\hline
\end{tabular}

et al. 1977). At least 10 fields or 300 cells were counted per sample, aiming at $\pm \mathrm{SE}<5 \%$

The standard deviation of 3 replicate sampling bottles representing the natural variability was estimated to average $\pm 5 \%$ (data not shown)

Bacterial secondary production. Bacterial growth was estimated with the thymidine incorporation technique essentially according to Fuhrman \& Azam (1982) on samples collected at 0 , $4,8,14,20,40,60,80$ and $100 \mathrm{~m}$

Sampling was performed every second week during April to September and approximately monthly during the rest of the year. Samples were taken at discrete depths with 51 Niskin-type bottles with Teflon seals (Hydro-Bios). The vertical distribution of samples was $0,4,8,14,20,40,60,80$ and $100 \mathrm{~m}$ (20 $\mathrm{m}$ maximum depth at the coastal station) on most sampling occasions.

Temperature, salinity and pH. Temperature and salinity were measured continuously through the water column with a calibrated CTD-probe UCM 40 MkII (Simtronix Environmental Monitoring a/s, Norway).

Light irradiance. Light irradiation at discrete depths was measurea win a circuidı yuaniun meies ius pisutosynthetically active light $\left(400\right.$ to $800 \mathrm{~nm}$, Li-Cor ${ }^{\mathrm{TM}}$, LI-188, Nebraska, USA). Measurements were performed primarily around 09:00 h, above surface and at $0,1,2,4,6,8,10,14$, and $20 \mathrm{~m}$. The number of observations during the year was 16,19 and 16 for Stns A13, B3 and C1, respectively.

Phytoplankton carbon fixation. The growth of phytoplankton was determined by the ${ }^{14} \mathrm{C}$ bicarbonate techniques described earlier (Gargas 1975, Larsson \& Hagström 1982, Andersson et al. 1996). Radioactive carbonate $\left(6 \mu \mathrm{Ci}, 0.1 \mathrm{mCi} \mathrm{mmol}^{-1}\right)$ was added to samples collected at depths $0,1,2,4,6,8,10,14$ and $20 \mathrm{~m}$ and incubated in situ for 3 to $4 \mathrm{~h}$ around 12:00 h. The incorporation of isotope into whole water was determined in $5 \mathrm{ml}$ acidified subsamples. Values were transformed to daily rates by multiplying with the ratio between the daily irradiation and the irradiation during the incubation period as described in Andersson et al. (1996).

The standard deviation of triplicates was determined to average $\pm 29 \%(n=30)$.

Bacterioplankton abundance. Samples for bacterioplankton counts were collected at $0,4,8,14,20,40,60$, 80 and $100 \mathrm{~m}$ and preserved with formaldehyde $(2 \%$ final conc.). Samples were subsequently (within $2 \mathrm{wk}$ ) stained with acridine orange $\left(600 \mu \mathrm{g} \mathrm{ml}^{-1}\right.$ final conc.) and counted in an epifluorescence microscope (Hobbie depth. $\left[{ }^{3} \mathrm{H}\right.$-methyl]-thymidine was added to triplicate (partly duplicate) $5 \mathrm{ml}$ samples and controls at a final concentration of $24 \mathrm{nM}$, determined to give a saturating concentration of thymidine. Controls were pretreated with $0.25 \mathrm{ml} 5 \mathrm{M} \mathrm{NaOH}$ for $10 \mathrm{~min}$. Samples and controls were incubated $1 \mathrm{~h}$ at the in situ temperature in the euphotic zone and aphotic zone, respectively. Incubations were terminated by adding $0.25 \mathrm{ml}$ $5 \mathrm{M} \mathrm{NaOH}$ and then precipitated with ice-cold $10 \%$ TCA. The precipitate was collected on $0.2 \mu \mathrm{m}$ polycarbonate filters (MSI) and washed repeatedly with $5 \%$ trichloroacetic acid, with and without the lid of the multi-filter unit. Dried filters were counted in the scintillation counter (LKB ${ }^{(0)}$ Optiphase Hisafe III scintilla-

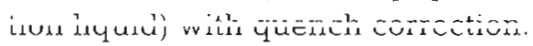

The amount of incorporated radioactive thymidine was converted to cells produced with the factor $1.5 \times$ $10^{18}$ ( \pm SD 0.84 ) cells (mol thymidine) $)^{-1}$, assuming no systematic seasonal or spatial variation. This factor was derived from empirical experiments with triplicate cultures at the 3 sites (Table 2). Briefly, a natural bacterial assemblage was diluted 5 -fold in $0.2 \mu \mathrm{m}$ filtered (Polycarbonate) seawater, according to the dilution procedure of Kirchman \& Ducklow (1993). Bacterial numbers and thymidine incorporation were measured as described above at time intervals to estimate the aver-

Table 2. Determination of the thymidine conversion factor

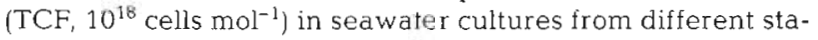
tions and sampling dates. TCF was determined by the integrative method. Number of replicate cultures (n), and the standard deviation of their mean are shown

\begin{tabular}{|lcccc|}
\hline Date & Stn & TCF & $\pm S D$ & $\mathrm{n}$ \\
\hline 29 Sep & B3 & 1.4 & 0.37 & 3 \\
28 May & B3 & 2.9 & 0.32 & 3 \\
11 Feb & B3 & 0.6 & 0.55 & 3 \\
13 Jun & A13 & 1.4 & 0.49 & 3 \\
14 Jun & C1 & 1.2 & 1.0 & 3 \\
Average & & 1.5 & 0.84 & 5 \\
atata supplied by Dr U. L. Zweifel & & \\
\hline
\end{tabular}


age thymidine conversion factor (TCF) for each culture as:

$$
\mathrm{TCF}=\frac{1}{n} \times \sum_{t=0}^{t=e} \frac{\mu \times N_{t}}{\mathrm{TdR}_{t}}
$$

where $N_{t}$ was the bacterial abundance at time $t_{1} \mathrm{TdR}_{t}$ the thymidine incorporation rate and $n$ the number of samples taken before the termination of the exponential growth phase $(t=e)$. The specific growth rate, $\mu$ (corresponding to the intrinsic rate of growth, $r$ ), was determined by solving the growth equation

$$
N_{t}=N_{0} \times e^{\mu \times t}
$$

by non-linear iteration using the statistical software SYSTAT ${ }^{\circledR}$ for $N_{i}$ during the exponential growth phase. The average TCF of the triplicate cultures at each experiment are shown in Table 2. These estimates were conservative compared to an analysis of the same data by the derivative method.

The average standard deviation of individual field estimates was determined to be $\pm 27, \pm 26$ and $\pm 24 \%$, at Stns A13, B3 and C1, respectively.

Nutrient analysis. $\mathrm{NH}_{4}, \mathrm{NO}_{2}, \mathrm{NO}_{3}$, total nitrogen (Tot-N), $\quad \mathrm{PO}_{4}$ and total phosphorus (Tot-P) were analysed with an autoanalyser (Technicon TRAACS 800) according to methods described by Grasshoff et al. (1983). Fifty $\mathrm{ml}$ of the samples were transferred to acid-rinsed polypropylene test tubes $\left(\mathrm{Nunc}^{\oplus}\right)$ and kept at $+4^{\circ} \mathrm{C}$ until further analysis (less than $24 \mathrm{~h}$ ). Dissolved organic nitrogen (DON) was determined by the difference between total nitrogen in the $0.2 \mu \mathrm{m}$ fraction (cellulose acetate filter, Sartorius ${ }^{\circledR}$ ), and the sum of inorganic nitrogen. Dissolved organic phosphorus (DOP) was calculated as total phosphorus in the $0.2 \mu \mathrm{m}$ fraction minus the phosphate concentration. The detection limit for $\mathrm{PO}_{4}, \mathrm{NH}_{4}$ and $\mathrm{NO}_{3}$ was $0.01,0.07$, and $0.05 \mu \mathrm{M}$, respectively.

DOC. For the determination of DOC, water samples were filtered through $0.2 \mu \mathrm{m}$ Gelman Supor filters using sterile syringe (Plastipak ${ }^{\infty}$ ) and filterholders (Millipore $^{\circledast}$ ) according to Zweifel et al. (1993). Filtered water $(7.5 \mathrm{ml})$ was collected in polypropylene test tubes (Falcon ${ }^{\otimes}, 15 \mathrm{ml}$ ) and immediately acidified with $100 \mu 1.2 \mathrm{M} \mathrm{HCl}$ to remove inorganic carbon. The samples were stored in the refrigerator $\left(+4^{\circ} \mathrm{C}\right)$ until analysis. The analysis was done within 1 wk of sampling in all cases, and most frequently within $48 \mathrm{~h}$. All material coming into contact with the samples was carefully rinsed with $1 \mathrm{M} \mathrm{HCl}$ and washed with ultrapure water (Millipore Milli-Q). DOC was measured with the high temperature catalytic oxidation method (HTCO) using a Shimadzu ${ }^{\otimes}$ TOC-5000 instrument, which had been subjected to international intercalibration (Peltzer et al. 1996). Samples of $150 \mu l$, injected in triplicate, showed standard deviations of 0 to $2 \%$.
The detection limit of the applied DOC protocol was $17 \mu \mathrm{M}$.

Statistical analysis. All data were initially examined graphically by scatter plot matrix (SPLOM) and normal probability plots in SYSTAT ${ }^{\circledast}$. Variables showing nonnormal distribution were ln-transformed before being subjected to parametric tests (e.g. most rate variables), while some state variables (e.g. $N_{\mathrm{b}}$ ) appeared approximately normally distributed. To conform to the relationship shown in Eq. (6) (see 'Results'), however, the analysis for Figs. 10-12 was done on non-transformed $P_{\mathrm{b}} / N_{\mathrm{b}}$ values. Where appropriate, residual analysis testing the assumptions underlying normal distribution was performed.

Association analysis: Patterns suggesting linear or non-linear associations were further investigated by re-plotting the variables in question. Pearson correlation analysis, combined with an estimate of associated Bonferroni probabilities of significance, was applied for linear relationships. Non-linear or multiple regressions were used where appropriate.

Regression analysis: Model I linear regressions were used where the independent variable was considered to contribute little to total variance. However, when measured variables contained an expected error term, Model II linear regression was applied. The loss term used corresponded to the major axis model recommended by the SYSTAT ${ }^{\oplus}$ Technical Support.

Prior to the analysis by multiple linear regression, a plausible model according to existing knowledge and with a minimum number of predictors was made. A forward, stepwise procedure was applied with ' $\mathrm{p}$ ' values to enter and remove set to 0.15 . Tolerance to avoid highly correlated predictors was set to 0.01 . SYSTAT ${ }^{\circledast}$ was used for the calculations.

Analysis of variance: Data was In-transformed and aggregated as appropriate before performing a Model II ANOVA. The mean squares produced by SYSTAT ${ }^{\circledR}$ was recalculated pooling sums of squares according to Sokal \& Rohlf (1995) when appropriate, prior to the significance test. For mean comparison the Bonferroni method was chosen.

\section{RESULTS}

\section{Spatiotemporal variation of bacterial production}

The integrated annual $P_{\mathrm{b}}$ was similar in the photic zone of both the offshore and coastal stations in the Bothnian Sea (Table 3). Corresponding values in the Bothnian Bay, however, were $25 \%$ lower. Integrated over the $100 \mathrm{~m}$ water column, the annual $P_{\mathrm{b}}$ was comparable at the 2 offshore stations but more than double that at the shallower coastal station. 
Table 3. Descriptive statistics of integrated bacterial cell production, cell numbers and specific growth rate in (a) the Bothnian Bay (Stn A13), (b) the Öre estuary (Stn B3) in the northern Bothnian Sea and (c) the open sea station in the Bothnian Sea (Stn C1). Data are given for the 4 major seasons as operationally defined by the Helsinki commission (HELCOM 1990); for Stns A13 and C1 data for the 2 major water layers, approximately divided by compensation depth, are given. Integrated bacterial cell production $\left(10^{12}\right.$ cells $\mathrm{dm}^{-2}$ period ${ }^{-1}$ ), bacterial abundance $\left(10^{12}\right.$ cells $\left.\mathrm{dm}^{-2}\right)$ and bacterial growth rate $\left(\mathrm{d}^{-1}\right)$ are specified. The latter 2 are given as integrated (weighted) averages for each time period (i.e. annual values may not be the sum of the seasons)

\begin{tabular}{|c|c|c|c|c|c|c|}
\hline $\begin{array}{l}\text { Variable } \\
\text { in }\end{array}$ & $\begin{array}{l}\text { Depth } \\
\text { interval }(\mathrm{m})\end{array}$ & Jan-Mar & Apr-Jun & Jul-Sep & Oct-Dec & Annually \\
\hline \multicolumn{7}{|c|}{ (a) Bothnian Bay (Stn A13) } \\
\hline \multirow[t]{3}{*}{ Growth rate } & e $\quad 0-20$ & 0.11 & 0.15 & 0.13 & 0.039 & 0.068 \\
\hline & $20-100$ & 0.067 & 0.19 & 0.075 & 0.055 & 0.058 \\
\hline & $0-100$ & 0.17 & 0.076 & 0.089 & 0.051 & 0.060 \\
\hline \multirow[t]{3}{*}{ Cell nos. } & $0-20$ & 0.23 & 0.43 & 0.45 & 0.28 & 0.28 \\
\hline & $20-100$ & 0.90 & 1.0 & 1.3 & 0.91 & 0.87 \\
\hline & $0-100$ & 1.1 & 1.4 & 1.7 & 1.2 & 1.0 \\
\hline \multirow[t]{3}{*}{ Cell prod. } & $0-20$ & 1.3 & 1.6 & 3.8 & 0.78 & 7.5 \\
\hline & $20-100$ & 3.0 & 5.0 & 6.4 & 3.7 & 18 \\
\hline & $0-100$ & 4.2 & 6.6 & 10 & 4.5 & 26 \\
\hline \multicolumn{7}{|c|}{ (b) Öre estuary (Stn B3) } \\
\hline Growth rate & e $\quad 0-20$ & 0.026 & 0.24 & 0.16 & 0.073 & 0.13 \\
\hline Cell nos. & $0-20$ & 0.10 & 0.23 & 0.44 & 0.30 & 0.28 \\
\hline Cell prod. & $0-20$ & 0.26 & 4.5 & 5.4 & 1.5 & 12 \\
\hline \multicolumn{7}{|c|}{ (c) Bothnian Sea (Stn C1) } \\
\hline \multirow[t]{3}{*}{ Growth rate } & e $\quad 0-20$ & 0.040 & 0.30 & 0.15 & 0.060 & 0.12 \\
\hline & $20-100$ & 0.060 & 0.13 & 0.11 & 0.070 & 0.078 \\
\hline & $0-100$ & 0.040 & 0.17 & 0.12 & 0.068 & 0.081 \\
\hline \multirow[t]{3}{*}{ Cell nos. } & $0-20$ & 0.080 & 0.36 & 0.62 & 0.35 & 0.28 \\
\hline & $20-100$ & 0.40 & 0.96 & 1.4 & 1.0 & 0.84 \\
\hline & $0-100$ & 0.50 & 1.3 & 2.0 & 1.4 & 1.2 \\
\hline \multirow[t]{3}{*}{ Cell prod. } & $0-20$ & 0.34 & 4.1 & 5.2 & 1.1 & 10 \\
\hline & $20-100$ & 3.3 & 4.8 & 7.1 & 3.4 & 19 \\
\hline & $0-100$ & 3.7 & 8.9 & 12 & 4.5 & 29 \\
\hline
\end{tabular}

largest share of $p_{\mathrm{b}}$ occurred during July-September in the whole water column. The season with lowest $P_{\mathrm{b}}$ differed between the stations, coinciding with October-December in the Bothnian Bay. The Bothnian Sea stations had their lowest production during the first quarter (January-March).

Analysing the discrete samples, we found that all stations showed increased $P_{\mathrm{b}}$ during the productive season in the euphotic zone (Fig. 2, Table 5b). The overall maximum value was found at the coastal station. Minimum values were higher at the coastal and the Bothnian Bay stations than at the offshore Bothnian Sea station in both depth layers. The variance at the scale of discrete 51 samples was lowest in the aphotic zone at both offshore stations. In the photic zone, the Bothnian Bay station showed the lowest variance of the 3 stations $(p<0.01$, Tables $5 \mathrm{~b} \& 6$ ). Highest variance in $P_{\mathrm{b}}$ occurred at the coastal station.

During the productive part of the year $P_{\mathrm{b}}$ at both open sea stations was cignificantly higher in the photic zame than the aphotic zone (ANOVA, p < 0.05). $P_{\mathrm{b}}$ in the photic zone of the Bothnian Bay was also significantly lower than in the Bothnian Sea $(p<0.03)$, as was also inferred from the integrated values (Table 4). However, during the winter season no significant differ-

The major part of the annual $P_{\mathrm{b}}$ at the open sea stations occurred at times when photosynthesis was reduced or lacking, despite the fact that the highest per volume $P_{\mathrm{b}}$ occurred in the photic zone during the productive season (Tables $3 \& 4$ ). Thus, as much as $79 \%$ of the annual $P_{b}$ at the Bothnian Bay station, and $68 \%$ at the Bothnian Sea station, occurred in the aphotic zone or during the colder and darker half of the year. In contrast, at the shallower coastal station $85 \%$ of $P_{\mathrm{b}}$ occurred during the productive half of the year.

$P_{\mathrm{b}}$ values for the 2 offshore stations compared well during the different seasons (Table 4). The exceptions were that the winter values were 5 times higher in the photic zone of the Bothnian Bay, and that spring rates (photic zone) there were half those in the southern basin. At all stations the ences between the habitats could be demonstrated. The ANOVA was performed on data aggregated over the productive (1 April to 31 September) and winter (1 October to $31 \mathrm{March}$ ) seasons, as well as the photic $(0$ to $20 \mathrm{~m}$ ) and aphotic zones (20 to $100 \mathrm{~m}$ ).

An episode of increased production occurred simultaneously at both offshore stations during January (Fig. 2).

Table 4. Relative bacterial production in different seasons and depth layers. Values are given as percentages of the annual total for the measured water column (100 $\mathrm{m}$ at the offshore stations, $20 \mathrm{~m}$ at the coastal station). See Table 3 for absolute values

\begin{tabular}{|lccccc|}
\hline Location & Depth interval (m) & Jan-Mar & Apr-Jun & Jul-Sep & Oct-Dec \\
\hline Bothnian Bay & $0-20$ & 5.0 & 6.4 & 15 & 3.0 \\
& $20-100$ & 12 & 19 & 25 & 14 \\
Öre estuary & $0-20$ & 2.2 & 39 & 46 & 12 \\
Bothnian Sea & $0-20$ & 1.2 & 14 & 18 & 3.7 \\
& $20-100$ & 11 & 16 & 24 & 12 \\
\hline
\end{tabular}


Bacterial biomass production

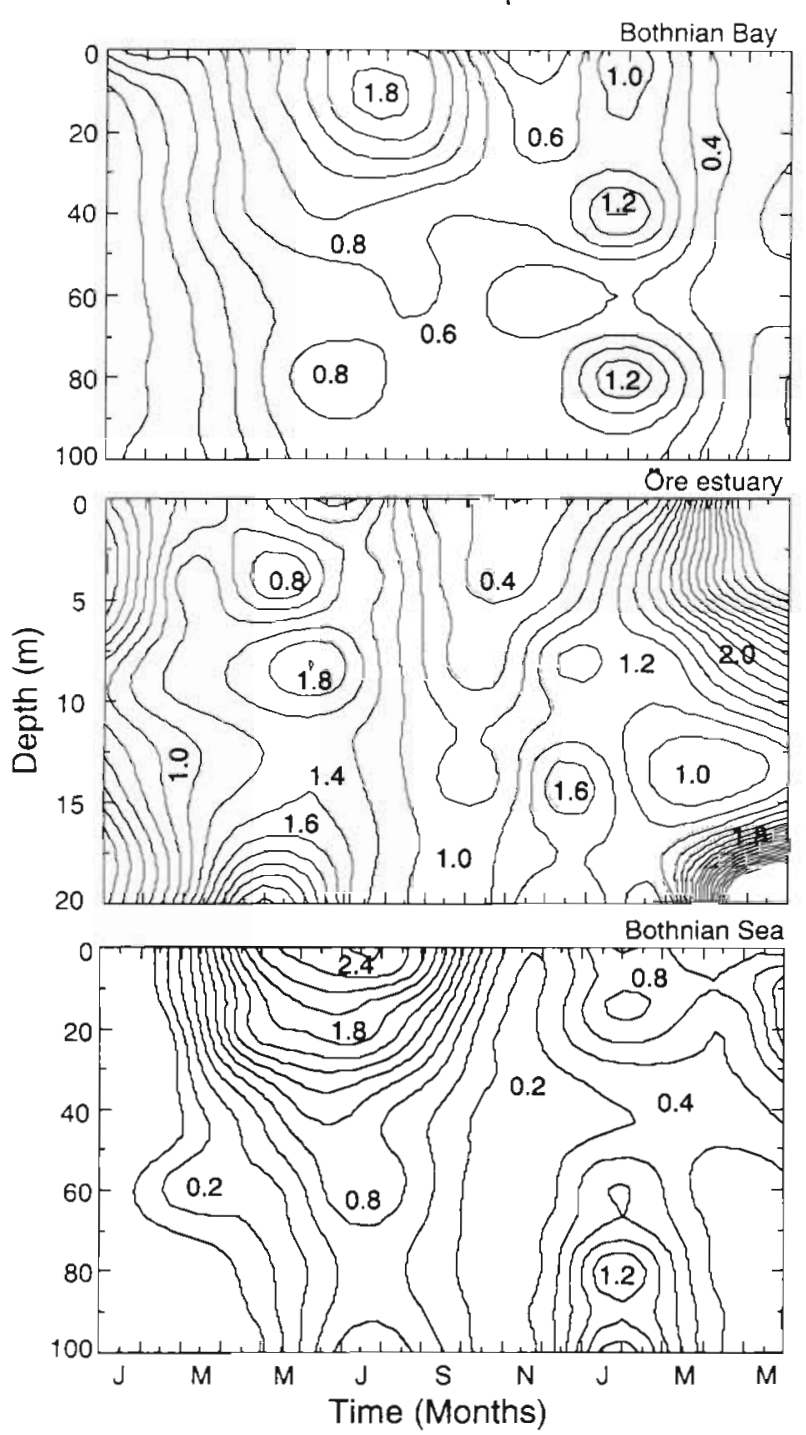

Fig. 2. Contour diagram of the bacterial production $\left(10^{8}\right.$ cells $\mathrm{l}^{-1} \mathrm{~d}^{-1}$ ) at the 3 stations. Isolines indicate differences of $0.2 \times$ $10^{8}$ cells $\mathrm{l}^{-1} \mathrm{~d}^{-1}$. Smoothing was done by the distanceweighted least squares (DWLS) method

We have not been able to reject these estimates as the result of methodological errors, as replicate variation and backgrounds showed typical values. In the 'Discussion' we put forward the hypothesis that discharge of river water, due to use of water power during the winter, may have promoted the high $P_{\mathrm{b}}$ values recorded in January.

\section{Spatiotemporal variation of bacterial abundance}

The annual average $N_{\mathrm{b}}$ in the 0 to $20 \mathrm{~m}$ layer was similar at all stations. Similar values were also observed at both offshore stations in the aphotic zone.

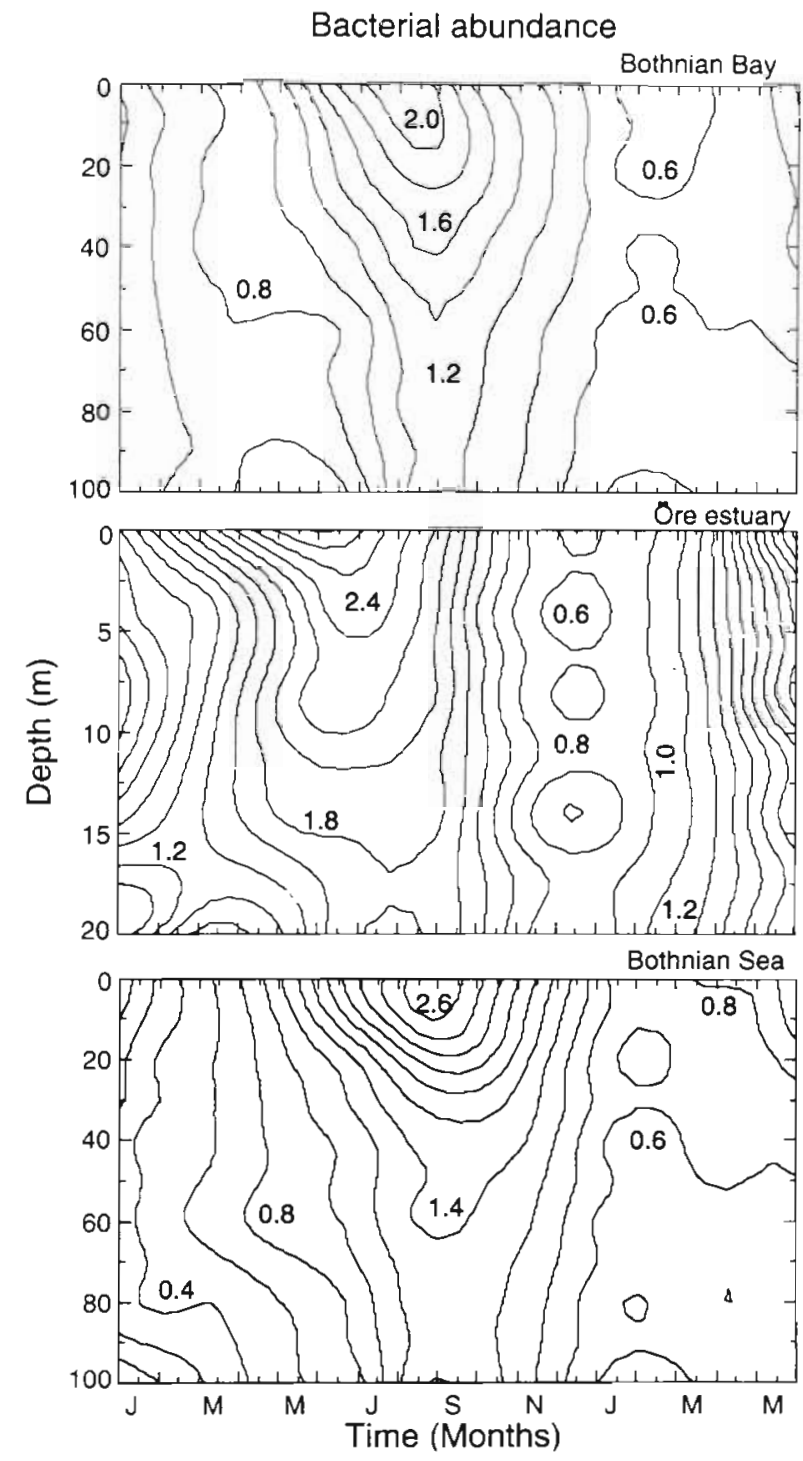

Fig. 3. Contour diagram of the bacterial abundance $\left(10^{9}\right.$ cells $\mathrm{I}^{-1}$ ) at the 3 stations. The isolines indicate differences of $0.2 \times$ $10^{9}$ cells $\mathrm{l}^{-1} \mathrm{~d}^{-1}$. Smoothing was done by the DWLS method

Significantly higher $N_{b}$ was demonstrated in the surface layer at both stations during summer $(p<0.001)$. However, no significant differences between stations could be demonstrated in either depth layer. Neither could any significant differences be demonstrated during winter. The ANOVA was run on data aggregated over the productive (1 April to 31 September) and winter (1 October to $31 \mathrm{March}$ ) seasons respectively, as well as the photic $(0$ to $20 \mathrm{~m}$ ) and aphotic zones (20 to $100 \mathrm{~m})$.

The coastal station showed the highest median $N_{\mathrm{b}}$ during the year and relatively low variability with depth (Fig. 3, Table 5a). Maximum and minimum val- 
Table 5. Descriptive statistics of (a) bacterial abundance $\left(10^{9}\right.$ cells $\left.1^{-1}\right)$, (b) bacterial biomass production $\times 10^{8}$ cells $\mathrm{I}^{-1} \mathrm{~d}^{-1}$; estimated detection limit: $0.1 \times 10^{8}$ cells $\mathrm{l}^{-1} \mathrm{~d}^{-1}$ [corresponding to $2 \mathrm{SD}$ ]) and (c) bacterial per capita growth rate $\left(\mathrm{d}^{-1}\right)$ at the different stations and depth layers in the Gulf of Bothnia

\begin{tabular}{|c|c|c|c|c|c|}
\hline Location De & $\begin{array}{l}\text { epth interval } \\
\text { (m) }\end{array}$ & Median & Maximum & Minimum & Variance \\
\hline \multicolumn{6}{|c|}{ (a) Bacterial abundance } \\
\hline Bothnian Bay & $\begin{array}{c}0-20 \\
20-100\end{array}$ & $\begin{array}{l}1.22 \\
0.89\end{array}$ & $\begin{array}{l}3.48 \\
1.96\end{array}$ & $\begin{array}{l}0.31 \\
0.26\end{array}$ & $\begin{array}{l}4.3 \\
1.6\end{array}$ \\
\hline Bothnian Sea & $\begin{array}{c}0-20 \\
20-100\end{array}$ & $\begin{array}{l}1.39 \\
0.85\end{array}$ & $\begin{array}{l}3.75 \\
1.96\end{array}$ & $\begin{array}{l}0.36 \\
0.22\end{array}$ & $\begin{array}{l}7.0 \\
1.7\end{array}$ \\
\hline $\begin{array}{l}\text { Öre estuary } \\
\text { (b) Bacterial b }\end{array}$ & $\begin{array}{l}0-20 \\
\text { biomass prod }\end{array}$ & $\begin{array}{r}1.60 \\
\text { uction }\end{array}$ & 3.60 & 0.32 & 4.7 \\
\hline Bothnian Bay & $\begin{array}{c}0-20 \\
20-100\end{array}$ & $\begin{array}{l}0.82 \\
0.58\end{array}$ & $\begin{array}{l}4.3 \\
2.5\end{array}$ & $\begin{array}{l}0.022 \\
0.037\end{array}$ & $\begin{array}{l}0.98 \\
0.25\end{array}$ \\
\hline Bothnian Sea & $\begin{array}{c}0-20 \\
20-100\end{array}$ & $\begin{array}{l}1.4 \\
0.41\end{array}$ & $\begin{array}{l}6.8 \\
2.4\end{array}$ & $\begin{array}{l}0.002 \\
0.009\end{array}$ & $\begin{array}{l}2.0 \\
0.30\end{array}$ \\
\hline $\begin{array}{l}\text { Öre estuary } \\
\text { (c) Bacterial p }\end{array}$ & $\begin{array}{l}\quad 0-20 \\
\text { per capita gro }\end{array}$ & $\begin{array}{c}1.7 \\
\text { wth rate }\end{array}$ & 12.1 & 0.046 & 6.8 \\
\hline Bothnian Bay & $\begin{array}{c}0-20 \\
20-100\end{array}$ & $\begin{array}{l}0.059 \\
0.052\end{array}$ & $\begin{array}{l}0.968 \\
0.458\end{array}$ & $\begin{array}{l}0.004 \\
0.004\end{array}$ & $\begin{array}{l}0.013 \\
0.007\end{array}$ \\
\hline Bothnian Sea & $\begin{array}{c}0-20 \\
20-100\end{array}$ & $\begin{array}{l}0.093 \\
0.043\end{array}$ & $\begin{array}{l}0.658 \\
0.651\end{array}$ & $\begin{array}{l}0.000 \\
0.001\end{array}$ & $\begin{array}{l}0.012 \\
0.013\end{array}$ \\
\hline Öre estuary & $0-20$ & 0.122 & 0.789 & 0.006 & 0.031 \\
\hline
\end{tabular}

\section{Spatiotemporal variation of bacterial specific growth rate}

$r_{\mathrm{c}}$ was calculated as the production to biomass ratio for the whole bacterial community (i.e. a community average). This variable includes the influence of competition and inactive or dead cells (i.e. is different from the commonly used specific growth rate, $\mu$ ). The median $r_{\mathrm{c}}$ was relatively similar in both the photic and aphotic zone of the Bothnian Bay station (Table $5 c$ ). $I_{c}$ in the photic zone at both Bothnian Sea stations was approximately double that in the Bothnian Bay. Minimum values were higher at the coastal and Bothnian Bay stations than in both water layers at the offshore Bothnian Sea station. Greatest variance in $r_{\mathrm{c}}$ was observed at the coastal station, while the variance was lowest in the aphotic zone of the Bothnian Bay.

Highest $I_{c}$ consistently occurred during April-June at all stations and in both depth layers (integrated values, Table 3). Therefore, the seasons with highest $r_{i}$ and $D_{i}$ did not rninrids

ues were similar at all stations and depth layers. Greatest variance was observed in the photic zone of the offshore station in the Bothnian Sea.

Maximum values were reached simultaneously at all stations in the beginning of August. Minimum values also occurred simultaneously at all stations in February.

Integrated $N_{\mathrm{b}}$ showed highest values during July-September at all stations, in accordance with $P_{\mathrm{b}}$ (Table 3). Lowest $N_{\mathrm{b}}$ occurred during January-March at both the Bothnian Sea stations, while $N_{\mathrm{b}}$ was of similar magnitude in both the fourth and first quarter at the Bothnian Bay station. At the of fshore stations $74 \%$ (Bothnian Bay) and $69 \%$ (Bothnian Sea) of the bacterial biomass occurred in the deeper 20 to 100 m layer of the water column.

Table 6. F-test of the null hypothesis that there was no difference in the variances for the Bothnian Bay (BB) versus the Bothnian Sea (BS) and the Öre estuary (OEE). The photic and aphotic zones were analysed separately. The variance of Bothnian Bay was significantly lower in all cases where $F_{\mathrm{s}}$ values were above $F_{0.025}$. See also Table 5a,b. ns: non-significant

\begin{tabular}{|lcccc|}
\hline & \multicolumn{2}{c}{ Bacterial biomass production } & \multicolumn{2}{c|}{ Bacterial numbers } \\
& BS vs BB & OE vs BB & BS vs BB & ÖE vs BB \\
\hline Photic zone & $<0.01$ & $<0.002$ & $<0.05$ & ns \\
Aphotic zone & ns & - & ns & - \\
\hline
\end{tabular}

(see above). $I_{\mathrm{c}}$ was also relatively high in the surface layer during January-March at the Bothnian Bay station, as compared to the other stations.

\section{Association between bacterial production, bacterial abundance and the specific growth rate}

The intra-annual variation in $P_{\mathrm{b}}$ was best associated with the $I_{C \prime}$ irrespective of station and depth layer investigated (Fig. 4). In the pooled data set for all stations and depth layers, $P_{\mathrm{b}}$ showed a Pearson correlation of $r=0.926\left(p_{r}<0.001\right)$ and $0.390\left(p_{r}<0.001\right)$ with $r_{\mathrm{C}}$ and $N_{\mathrm{b}}$, respectively (both natural logarithm [ln] transformed). A multiple regression analysis with $N_{\mathrm{b}}$ and $r_{c}$ as independent variables gave the standardised coefficients 0.360 and 0.914 for the variables, respectively, showing that the effect of $r_{\mathrm{c}}$ on $P_{\mathrm{b}}$ was greater than that of $N_{\mathrm{b}}$. However, given the standard tolerance factors used $\left(T_{\min }=\right.$ 0.01 ), the resulting subset model retained both variables. Thus, both $N_{\mathrm{b}}$ and $r_{\mathrm{C}}$ contributed significantly to explain the variance in $P_{\mathrm{b}}$, although the latter showed a more than 2-fold higher correlation. 


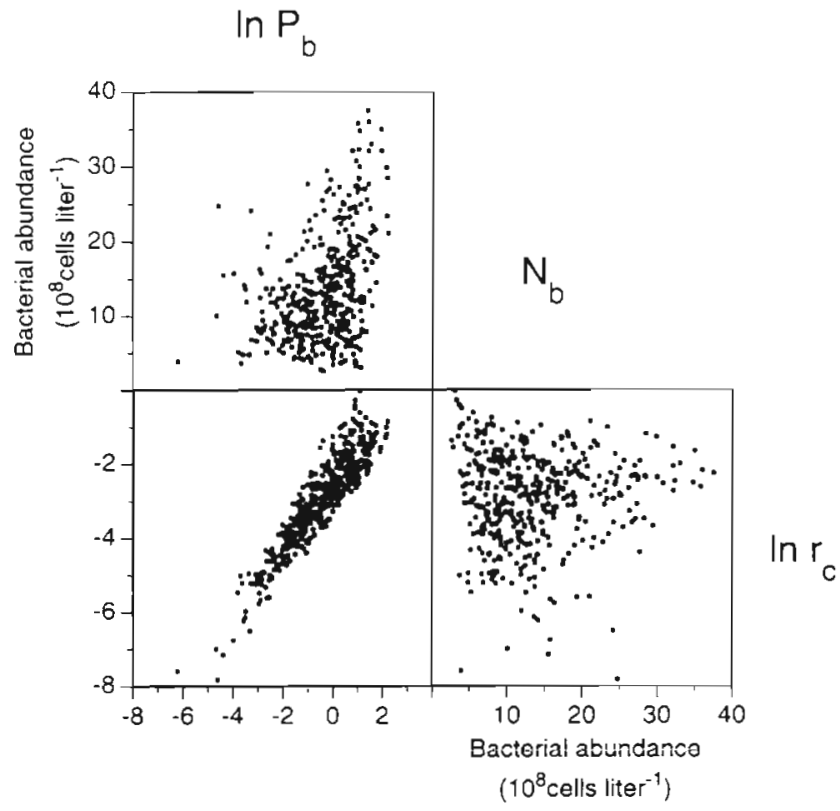

Fig. 4. Association between bacterial cell production $\left(P_{b}\right)$, specific growth rate $\left(r_{c}\right)$ and numbers $\left(N_{b}\right)$ when all stations and depths were pooled. $r_{\mathrm{c}}$ showed a significant Pearson correlation $\left(\mathrm{p}_{\mathrm{r}}<0.001\right)$ of $\mathrm{r}=0.980$, and $N_{\mathrm{b}}$ showed a corresponding significant value of $r=0.362$

Caution should however be used when interpreting these relationships since autocorrelation is expected between the numerator, denominator and their ratio. Therefore, a Gauss approximation was made as a less dubious complement to distinguish between the contribution of the numerator and denominator to the variance of a ratio (GUM 1993, Peter Anton, Dept. of Mathematical Statistics, Umeå University, pers. comm.). This alternative analysis gave the same result as the association analysis, suggesting that a variation in $r_{\mathrm{c}}$ explained more of the variation in $P_{b}$ than $N_{b}$. The variance of the ratio, $V(x / y)$, is a function of the variance $\left(\sigma_{x}{ }^{2}\right)$ and mean value $\left(\mu_{x}\right)$ of the numerator and the corresponding values for the denominator $\left(\sigma_{y}{ }^{2}\right.$ and $\left.\mu_{y}\right) . V(x / y)$ can therefore be approximated as

$$
V\left(\frac{x}{y}\right)=\frac{\mu_{y}^{2} \sigma_{x}^{2}+\sigma_{y}^{2} \mu_{x}^{2}}{\mu_{y}^{4}}
$$

The variance and squared mean of the $P_{\mathrm{b}}$ variable (i.e. $\sigma^{2}{ }_{x}$ and $\mu^{2}{ }_{x}$ ) over the study period in the estuarine environment were 2.786 and 1.949 , respectively, and the corresponding parameters for $N_{b}$ were 48.093 and 170.903 . The amount of variance in $r_{\mathrm{c}}$ explained by $P_{\mathrm{b}}$ was approximately $1.63 \times 10^{-2}$, while that explained by $N_{b}$ was ap-

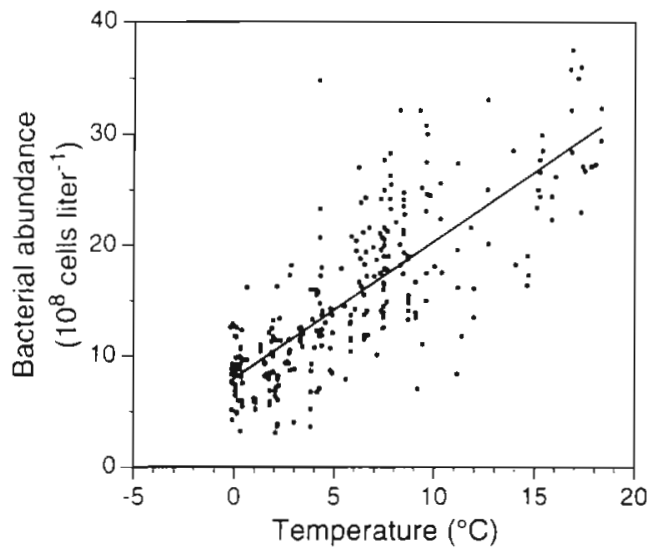

Fig. 5. Bacterial cell numbers as a function of temperature in the 0-20 m layer. All stations wcre pooled. A linear regression showed that temperature explained $51 \%\left(r^{2}=0.508\right)$ of the variation in bacterial abundance in the surface layer according to the relationship $N_{\mathrm{b}}=8.77+1.05 T$ (all stations pooled, $\mathrm{p}<0.001 \times 10^{8}$ cells $\mathrm{I}^{-1}$ ). The $95 \% \mathrm{CI}$ (confidence interval) for the constant and slope was \pm 0.86 and \pm 0.11 , respectively

proximately $3.21 \times 10^{-3}$. Therefore, $P_{\mathrm{b}}$ contributed about 5 times more to the variance of the $r_{\mathrm{c}}$ variable than $\operatorname{did} N_{\mathrm{b}}$. As in the association analysis, this suggested that $r_{c}$ was the major source of the intra-annual variation in $P_{\mathrm{b}}$, rather than $N_{\mathrm{b}}$.

\section{Association between bacterial concentration, temperature and salinity}

Due to the hydrographic association between in situ temperature $(T)$ and salinity $(S)$, they were analysed together by a stepwise multiple regression (Table 7 . Figs. $5 \& 6$ ). $T$ was a positive predictor of the $N_{\mathrm{b}}$ in the

Table 7. Summary of models and statistical results from multiple regression of bacterial abundance on in situ temperature $(T)$ and salinity (S). All results are for the photic zone. The general model $N_{b}=C+a T+b S$ was applied. $N_{b}$ was in units of $10^{8} \times$ cells $^{-1}, T$ in ${ }^{\circ} \mathrm{C}$ and $S$ in psu. The coefficients and their significance level $(p)$, standard error $( \pm S E)$, as well as the adjusted multiple coefficient of determination $\left(\mathrm{R}_{\mathrm{adj}}^{2}\right.$ ) are shown. All associated ANOVA analyses were significant $(p<0.05)$

\begin{tabular}{|lcccc|}
\hline Location & $C$ & a (temperature) & $b$ (salinity) & $R^{2}$ adj \\
\hline Bothnian Bay & 8.20 & 1.00 & - & 0.607 \\
$\mathrm{p}$ & $<0.001$ & $<0.001$ & $\mathrm{~ns}$ & $<0.01$ \\
$\pm \mathrm{SE}$ & 0.61 & 0.080 & - & - \\
Ore estuary & 22.36 & 1.11 & -7.33 & 0.633 \\
$\mathrm{p}$ & 0.009 & $<0.001$ & 0.129 & $<0.01$ \\
$\pm \mathrm{SE}$ & 8.3 & 0.13 & 5.0 & - \\
Bothnian Sea & 155 & 0.844 & -83.8 & 0.693 \\
$\mathrm{p}$ & 0.026 & 0.024 & 0.037 & $<0.01$ \\
$\pm \mathrm{SE}$ & 50 & 0.27 & 28 & - \\
\hline
\end{tabular}




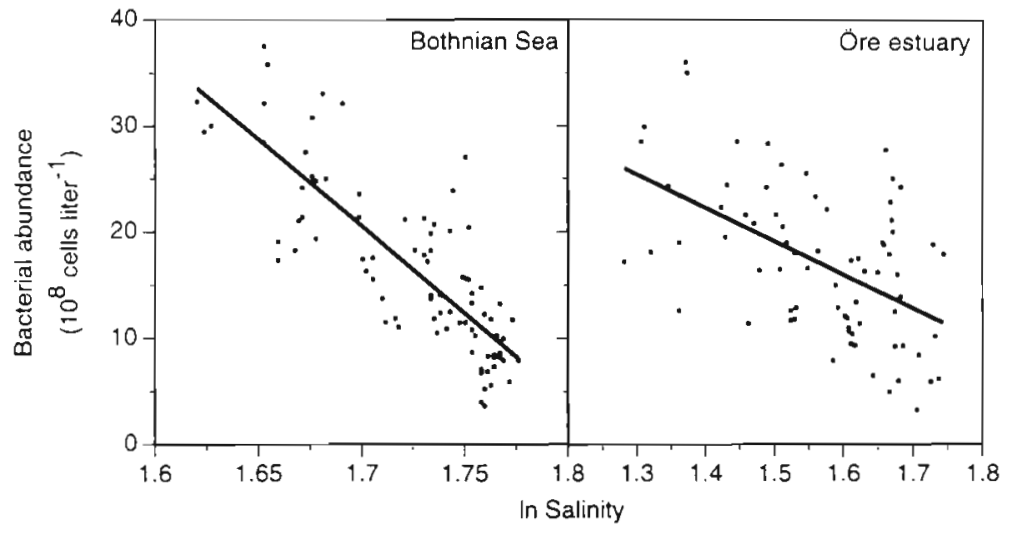

Fig. 6. Bacterial numbers as a function of salinity in the surface water of the offshore and coastal station in the Bothnian Sea. A significant negative correlation was found for both the open sea $\left(r=0.816, p_{r}<0.001\right)$, and the coastal stations $\left(r=0.531, \mathrm{p}_{\mathrm{r}}<0.001\right)$

photic zone at all stations. $S$ was retained as a negative predictor at both the offshore and coastal stations in the Bothnian Sea. For $T$, the slope coefficient was not significantly different at the 3 stations and close to unity. For $S$, a negative slope coefficient clearly steeper than at the coastal station was observed at the offshore Bothnian Sea station.

Nearly $70 \%$ of the intra-annual variation in $N_{\mathrm{b}}$ could be explained by a variation in $T$ and $S$ at the nffchoro Rnthnian Soa station. $\Delta t$ the coastal statinn the corresponding value was $64 \% . T$ alone explained $61 \%$ of the variation in $N_{\mathrm{b}}$ in the Bothnian Bay. The standardised coefficient suggested an equal impact of $T$ and $S$ at the offshore Bothnian Sea station (standard coefficients $=0.44$ and -0.42 , respectively), while $T$ had a clearly greater impact at the coastal station $(0.72$ and -0.13 , respectively). We therefore conclude that $T$ alone, or $T$ together with $S$, consistently explained the major part of the intra-annual variation in $N_{\mathrm{b}}$ in the photic zone at the study stations.

No similar association could be demonstrated for the aphotic zone at either offshore station $\left(R^{2}{ }_{\text {ad }}<0.11\right)$. Thus, neither $T$ nor $S$ could explain the variation in $N_{\mathrm{b}}$ in the aphotic zone.

\section{Association between bacterial concentration and DOC}

Specifically for the Bothnian Bay a significant linear association between $N_{\mathrm{b}}$ and bulk DOC $\left(S_{\mathrm{DOC}}, \mu \mathrm{M}\right)$ was observed in the aphotic zone (Fig. 7). The relationship was estimated to be:

$$
N_{\mathrm{b}}=-108+0.41 \times S_{\text {DOC }}
$$

with $\mathrm{p}<0.001$ for the coefficients and $\mathrm{r}=$ $0.830\left(\mathrm{p}_{\mathrm{r}}<0.01\right.$, in $10^{8}$ cells $\left.\mathrm{I}^{-1}\right)$. This relationship only occurred during periods when low sedimentation can be expected. Samples between the end of May and middle of June (both 1991 and 1992). coinciding with the spring bloom, were excluded (also 1 case from the end of March). These samples formed a clearly separate cluster in a plot between $N_{\mathrm{b}}$ and DOC concentration (data not shown). The result suggested that, during the period analysed, the concentration of bulk DOC was the main predictor of the standing stock of bacteria in the aphotic zone of the Bothnian Bay. Although a positive slope could be demonstrated for the aphotic zone of the Bothnian Sea, the Pearson correlation coefficient was much lower $(r=$ $\left.0.394, \mathrm{p}_{\mathrm{r}}<0.01\right)$.

\section{Association between bacterial per capita growth rate and temperature}

Logarithm-transformed $r_{\mathrm{c}}$ showed a non-linear association with temperature in the photic zone of the offshoro statinns at tomporatures ahore go ${ }^{\circ}$ (Fig 8). The samples in question coincided with the period of the most pronounced stratification during the year (Fig. 9). At the coastal station the general pattern was similar to that in the photic zone of the offshore stations; however, the variability during the stratified period was too high to allow a significant fit to the applied model. No similar clear association could be demonstrated in the aphotic zone within the observed temperature ranges

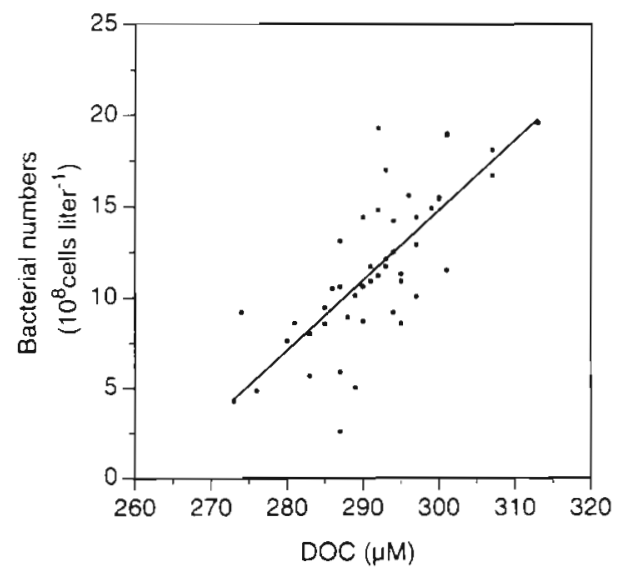

Fig. 7. Association between the bacterial and DOC concentrations in the aphotic zone $(20-100 \mathrm{~m})$ of Bothnian Bay. Samples from May until the middle of July were excluded (i.e. those with marked sedimentation). A significant correlation was found $\left(r=0.830, p_{r}<0.001\right)$ 


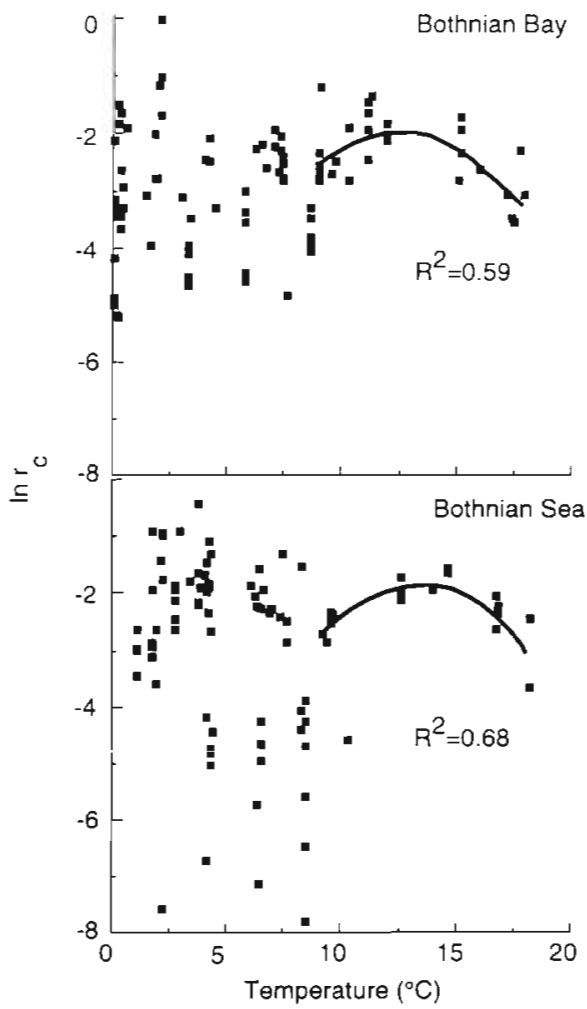

Fig. 8. Bacterial specific growth rate as a function of temperature in the surface layer $(0-20 \mathrm{~m})$ of the Bothnian Bay and the Bothnian Sea. A significant non-linear relationship was found during stratification of the water column

of -0.1 to $10.3^{\circ} \mathrm{C}$ (Bothnian Bay) and 1.0 to $6.6^{\circ} \mathrm{C}$ (Bothnian Sea); neither was an association apparent during seasons without marked stratification in the photic zone (i.e. below $9^{\circ} \mathrm{C}$, Fig. 8).

The applied second-order power function for data of the stratified photic zone of the Bothnian Sea showed that the in situ temperature $(T)$ explained $68 \%\left(\mathrm{p}_{\mathrm{r}}<\right.$ 0.01 ) of the variability in $r_{\mathrm{c}}$ (Fig. 8). This suggested that $T$ directly or indirectly controlled $I_{\mathrm{c}}$ in the stratified photic zone. The corresponding coefficient of determination for the Bothnian Bay was slightly lower $\left(\mathrm{R}^{2}=\right.$ $\left.0.59, \mathrm{p}_{\mathrm{r}}<0.05\right)$. The second derivative indicated maximum $r_{\mathrm{c}}$ at $T$ values of 13.4 and $10.6^{\circ} \mathrm{C}$ in the Bothnian Sea and Bothnian Bay, respectively. As there is no theoretical basis for a hyperbolic dependence of $\ln r_{\mathrm{c}}$ on $T$, and data are valid for the community rather than the population level, we cannot give the coefficients an ecological meaning based on this study alone.

The data points selected for the non-linear model aggregated homogeneously between Julian days 191 and 260 and depths of 0 to $8 \mathrm{~m}$ in the Bothnian Sea and of 0 to $14 \mathrm{~m}$ in the Bothnian Bay.

$r_{\mathrm{C}}$ should be a function of $T$ according to the Arrhenius equation (Stanier et al. 1980). The linear portion of the curves preceding the maximum value of $r_{\mathrm{c}}$ showed a significant relationship for $r_{\mathrm{c}} \alpha T^{-1}(\mathrm{~K})$ at the Bothnian Sea station $\left(\mathrm{r}^{2}=0.84, \mathrm{p}<0.001\right)$, showing a $Q_{\mathrm{t} 0}$ value of 5.8 within the studied range. The corresponding data for the Bothnian Bay was also significant, albeit at a lower level of explanation $\left(r^{2}=0.54, p<0.01\right)$, showing an unrealistically high $Q_{10}$ of 27 . We infer that the data points below the value of $T$ at which $r_{\mathrm{c}}$ was a maximum during stratification were too few to allow an estimate of $Q_{10}$ in the Bothnian Bay.

\section{Association between bacterial per capita growth rate and bacterial abundance}

In a plot of $r_{\mathrm{c}}$ versus $N_{\mathrm{b}}$, a negative slope would be expected if intra- or inter-species competition occurs

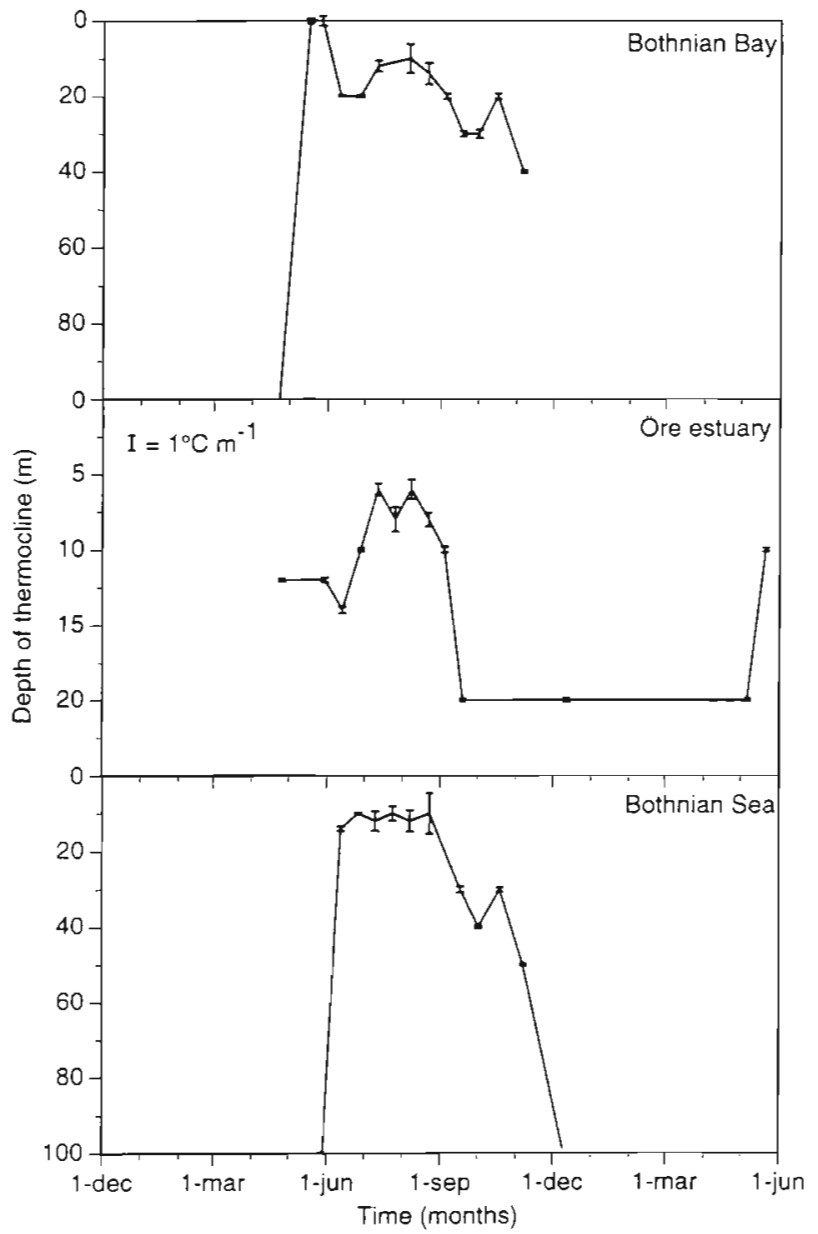

Fig. 9. Depth of the thermocline as a function of time at the different stations. Error bars correspond to the strength of the thermocline in ${ }^{\circ} \mathrm{C} \mathrm{m}^{-1}$ (cf. standard bar in the Ore estuary panel). Only thermoclines with a strength exceeding $0.1^{\circ} \mathrm{C}$ $\mathrm{m}^{-1}$ are shown. Note that a weak thermocline during winter could occur down to $100 \mathrm{~m}$. Missing values are due to values below the detection limit or missing data 


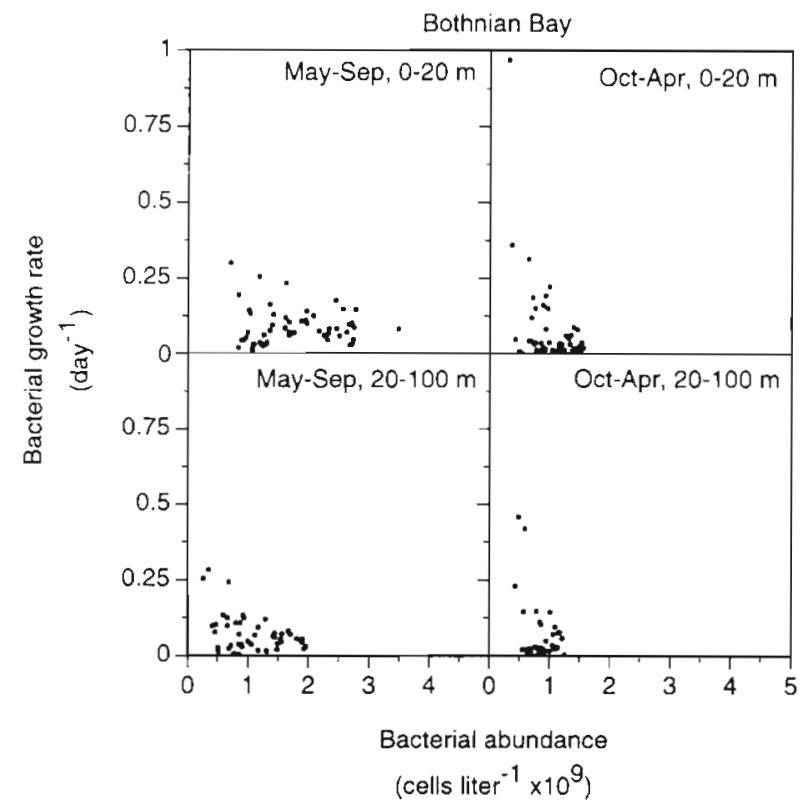

Fig. 10. Test of the occurrence of competition by plotting $I_{c}$ versus $N_{b}$ for the data collected in Bothnian Bay (Stn A13). The independent variable $\left(N_{\mathrm{b}}\right)$ indirectly indicates the course of events during the periods. Thus, $N_{\mathrm{b}}$ in general increased (moved from left to right) during the summer season, but decreased (moved from right to left) during the winter seasons. See text for further analysis

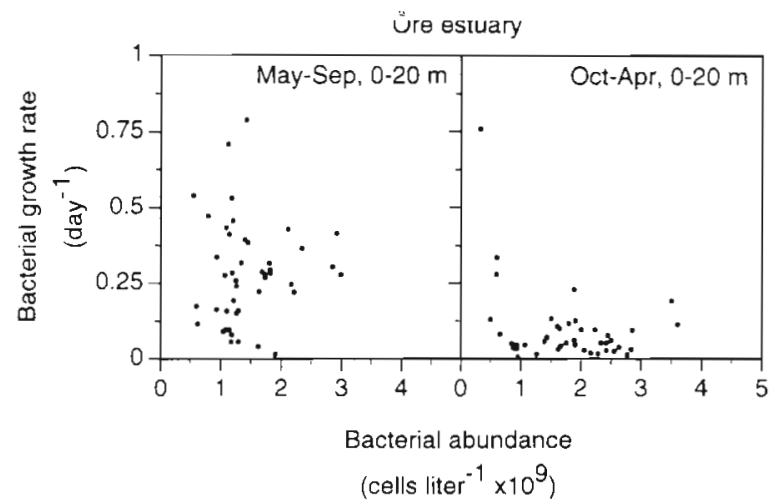

Fig. 11. Test of the occurrence of competition by plotting $r_{c}$ versus $N_{b}$ for the data collected at the coastal station in the Bothnian Sea (Stn B3). See Fig. 10 legend for details

(Begon et al. 1988). The growth rate per cell is expected to be related to the carrying capacity $(K)$, the cell abundance $(N)$ and $r$, the intrinsic rate of natural increase in the absence of competition (i.e. corresponding to $\mu$ in microbiological literature) according to the following function:

$$
\frac{\mathrm{d} N}{\mathrm{~d} t} \times \frac{1}{N}=\frac{-r}{K} \times N+r
$$

Preliminary plots of $r_{\mathrm{c}}$ (corresponding to the left side of Eq. 6) versus $N_{b}$ suggested different relationships

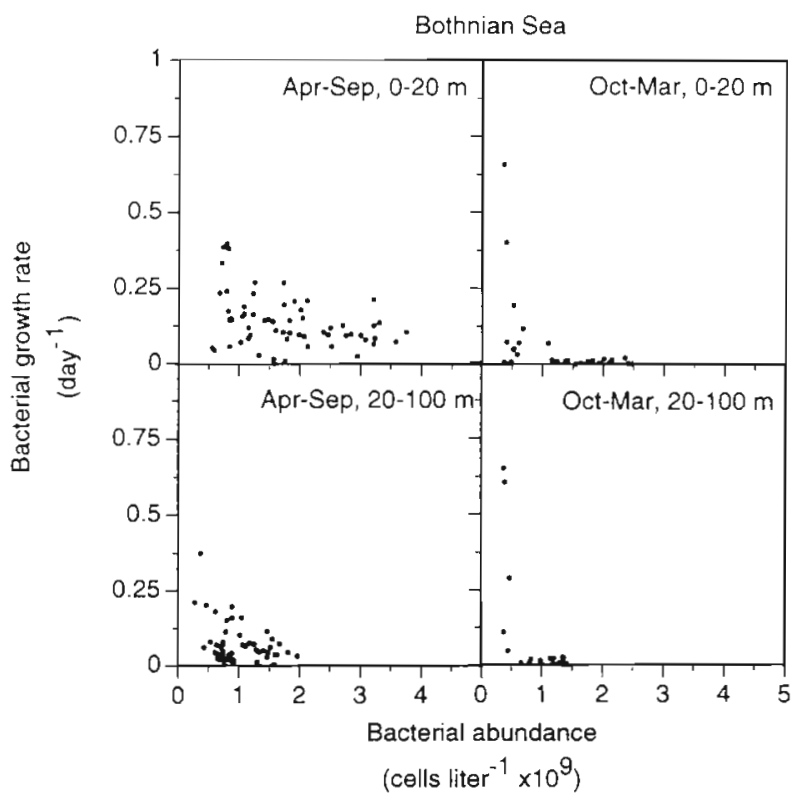

Fig. 12. Test of the occurrence of competition by plotting $r_{\mathrm{C}}$ versus $N_{\mathrm{b}}$ for the data collected at the offshore station in the Bothnian Sea (Stn C1). See Fig. 10 legend for details

during the major periods of net increase and decrease in $N_{\mathrm{b}}$, respectively. These periods were approximately divided by the annual maximum. Therefore, data were

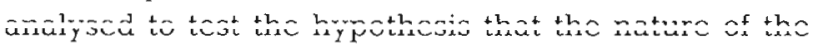
competition varied with the major seasons and the depth interval. Figs. 10-12 show that clear negative relationships occurred during the winter season at all sites. During the productive season a marked negative slope (model II regression) could only be demonstrated in the aphotic zone at the offshore stations (Table 8).

In the photic zone during summer slopes were nonsignificant or weak (Bothnian Sea photic zone AprilSeptember), indicating that competition was not a major factor controlling $x_{\mathrm{c}}$ when $P_{\mathrm{b}}$ was at summer levels. Plotting $P_{\mathrm{b}}$ directly versus $N_{\mathrm{b}}$ corroborated this result by showing a statistically significant positive slope at all stations. This relationship was most clear at the coastal station (slope $=0.38,95 \% \mathrm{CI}= \pm 0.13, \mathrm{r}=$ 0.64 ), while correlation coefficients were 0.54 and 0.49 at the Bothnian Bay and Bothnian Sea stations, respectively.

The coefficients of Eq. (6) were determined during periods indicating a linear relationship between $r_{\mathrm{c}}$ and $N_{\mathrm{b}}$ (i.e. when $N_{\mathrm{b}}$ was below $K$, see 'Discussion'). When a sufficient correlation allowed estimates of the coefficients, the general trend was that high $K$ and low $r$ was observed during the period when sedimentation was expected to be a major source of substrate in the aphotic zone (Table 8). In contrast, winter values consistently showed high $\mathrm{r}$ and low $K$ communities. All but 1 estimate of $\mathrm{I}$ was statistically significant, while all 
Table 8. Coefficients for the density dependence of bacterial growth rate by a model Il regression according to Eq. (6). Data are shown in Figs. 10-12. The intrinsic growth rate with negligible influence from bacterial density, $r\left(\mathrm{~d}^{-1}\right)$, was equal to the $y$-intercept and the carrying capacity, $K\left(10^{9}\right.$ cells $\left.\mathrm{l}^{-1}\right)$, was derived by calculation from the derived coefficients (i.e. the $x$-intercept). The estimated $95 \%$ confidence interval for the coefficients is shown $( \pm \mathrm{Cl})$. Calculations was only made when the slope and $y$-intercept was significantly different from zero $(p<0.05)$. ns Slope was not significantly different from zero. The correlation coefficient is shown. Coefficients were calculated for the Bothnian Sea in October-March, despite a non-significant slope due to the indication of density limitation in the overall graphic patterrn

\begin{tabular}{|c|c|c|c|c|c|c|c|}
\hline Station & Period & $\begin{array}{c}\text { Depth } \\
\text { interval }(\mathrm{m})\end{array}$ & $r$ & $\pm \mathrm{Cl}$ & $K$ & $\pm \mathrm{CI}$ & $\begin{array}{c}\text { Correlation } \\
\text { coefficient }\end{array}$ \\
\hline Bothnian & May-Sep ${ }^{\text {ns }}$ & $0-20$ & - & - & - & - & -0.030 \\
\hline \multirow[t]{3}{*}{ Bay } & Oct-Apr & $0-20$ & 0.91 & 0.51 & 0.86 & 0.85 & -0.464 \\
\hline & May-Sep & $20-100$ & 0.13 & 0.043 & 2.4 & 1.6 & -0.421 \\
\hline & Oct-Apr & $20-100$ & 0.58 & 0.31 & 0.86 & 1.7 & -0.440 \\
\hline Öre & Apr-Aug ${ }^{n s}$ & $0-20$ & - & - & - & - & -0.041 \\
\hline estuary & Sep-Mar & $0-20$ & 0.96 & 0.42 & 0.88 & 0.68 & -0.332 \\
\hline Bothnian & Apr-Sep & $0-20$ & 0.20 & 0.049 & 5.7 & 0.06 & -0.346 \\
\hline \multirow[t]{3}{*}{ Sea } & Oct-Mar ${ }^{n s}$ & $0-20$ & 0.62 & 0.78 & 0.68 & 1.6 & -0.264 \\
\hline & Apr-Sep & $20-100$ & 0.13 & 0.048 & 2.3 & 0.07 & -0.327 \\
\hline & Oct-Mar & $20-100$ & 0.91 & 0.69 & 0.75 & 1.3 & -0.655 \\
\hline
\end{tabular}

bon fixation (Table 4 ). Only $31 \%$ of the $P_{\mathrm{b}}$ coincided with the photic zone and productive season where phytoplankton carbon fixation is important. This was unexpected as the annual phytoplankton carbon fixation is estimated to account for $90 \%$ of the carbon supply in this basin, markedly higher than the allochthonous supply (Elmgren 1984).

The lack of a clear correlation between carbon fixation at discrete depths and $P_{\mathrm{b}}$ (in the photic zone only) further suggested that a clear time lag between phytoplankton carbon fixation and bacterial utilisation of phytoplankton exudates occurred. A marked dispersion of phytoplanktonderived DOC by advection and sedimentation must therefore have taken place before being taken up by bacteria. During this time phytoplankton cells may have been transformed to

summer estimates of $K$ at both depth intervals were significant (including Bothnian Bay in winter). However, we could not determine the values of $r_{\mathrm{C}}$ and $N_{\mathrm{b}}$ during the periods when no significant relationship occurred (i.e. photic zones during summer and winter at values above $1 \times 10^{9}$ cells $^{-1} \mathrm{l}^{-1}$ ).

\section{Other associations}

A negative association between $N_{b}$ and nitrate concentration was observed, but only for the Bothnian Bay $(0-20 \mathrm{~m}$, data not shown). The Pearson correlation coefficient was determined to be $0.770\left(\mathrm{p}_{\mathrm{r}}<0.01\right)$, the slope to be $-2.4\left(\mathrm{p}_{\mathrm{r}}<0.001\right)$ and the $y$-intercept to be 28 $(\mathrm{p}<0.001)$.

No significant correlation between phytoplankton carbon fixation and $r_{c}$ or between carbon fixation and $N_{b}$, could be demonstrated in this study. In the Bothnian Sea, where the most marked seasonal pulse of carbon fixation was observed, the correlation coefficient was non-significant (>0.05, $\mathrm{n}=58$ ) and $r$ was low (0.220 and 0.207 , for carbon fixation versus $I_{\mathrm{c}}$ and $N_{\mathrm{b}}$, respectively).

No clear relationship between any of the bacterial variables and other nutrient variables measured could be demonstrated.

\section{DISCUSSION}

Most of the annual $P_{\mathrm{b}}$ occurred outside the limited period and depth layer of marked phytoplankton car- the dissolved state by processes such as grazing, viral lysis and particle dissolution. Consequently, direct exudates from phytoplankton did not seem to be the major pathway providing bacterioplankton with reduced carbon compounds. This does not agree with conclusions from earlier studies suggesting direct exudation as a major pathway based on filter size fractionation of ${ }^{14} \mathrm{CO}_{2}$ uptake (e.g. Williams \& Yentsch 1976, Larsson \& Hagström 1979, Mague et al. 1980, Joiris et al. 1982).

The uncoupling of bacterioplankton growth from phytoplankton carbon fixation was most marked in the basin with the highest allochthonous input of DOC and longest residence time (Fig. 2, Tables 3, 4 \& 6). Allochthonous discharge of DOC to the Bothnian Bay is estimated to comprise $40 \%$ of the total carbon input (Pettersson 1992, Andersson et al. 1996). Only 22\% of the annual $P_{\mathrm{b}}$ occurred in the photic zone during the productive seasons in the Bothnian Bay. Accordingly, we could demonstrate that the variance of both $P_{\mathrm{b}}$ and $N_{\mathrm{b}}$ in the photic zone was significantly $(\mathrm{p}<0.05)$ lower in the Bothnian Bay than the Bothnian Sea (Tables 5 \& $6)$. The major difference between the basins was the higher winter $P_{\mathrm{b}}$ and lower spring $P_{\mathrm{b}}$ in the Bothnian Bay. In other seasons integrated values were remarkably similar at the offshore stations (Table 4).

One consequence of river regulation for hydroelectric power production is elevated discharge during winter time (Brydsten et al. 1990). We therefore propose that such elevated winter discharge contributed to the relatively high winter values in the Bothnian Bay by providing reduced organic compounds to the marine ecosystem. A higher availability of terrigenous 
DOC may also explain the higher minimum values of $P_{\mathrm{b}}$ and $r_{\mathrm{c}}$ that were a common feature of the 2 stations with greater allochthonous influence (Tables 4 \& 5). An important effect of high allochthonous DOC input to these coastal ecosystems was therefore to promote bacterial growth during periods when carbon supply from phytoplankton was low. Water power regulation likely made this effect more pronounced during winter in the northern basin.

The lower intra-annual variability of $P_{\mathrm{b}}$ observed in the Bothnian Bay was further in accordance with the relatively high $P_{\mathrm{b}}$ compared to autochthonous carbon fixation in this basin. The ratio of $P_{\mathrm{b}}$ to phytoplankton carbon fixation, integrated over the year at an average depth, amounted to $0.42,0.20$ and 0.22 , respectively, for the Bothnian Bay, the Öre estuary and the Bothnian Sea (autochthonous carbon fixation from Andersson et al. 1996). The short residence time of the Öre estuary, combined with a coincidence of the phytoplankton bloom and the spring flood of the non-regulated Ore river, likely reduced the importance of allochthonous carbon in the estuary.

From this we infer that terrigenous DOC constituted an important source of carbon and energy in the Bothnian Bay. Allochthonous DOC, given sufficient residence time, may therefore supply important $P_{\mathrm{b}}$ in coastal marine ecosystems (cf. Table 1). This contribu-

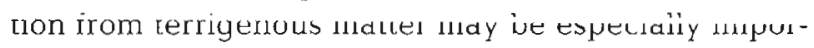
tant during periods of low phytoplankton productivity.

Uncoupling between bacterial and phytoplankton variables has previously been observed in the upper part of the Delaware estuary, Rhone River plume, Hudson River and the upper St. Lawrence Estuary (Findlay et al. 1991, Hoch \& Kirchman 1993 and references therein). At a sufficient allochthonous loading rate, bacterioplankton may thus be viewed as 'primary producers', bringing in 'new carbon' to the marine ecosystem. The potential of bacterioplankton to structure the food web and biogeochemistry of such estuaries may therefore be comparable to that of phytoplankton.

A common characteristic of the sites was that the $I_{c}$ and $P_{\mathrm{b}}$ showed their highest integrated values during different seasons (Table 3). Highest $r_{c}$ was found during spring in connection with high diatom productivity (i.e. spring bloom conditions, Andersson et al. 1996). Thus, the prime growth conditions appeared to coincide with supply of a high-quality substrate from spring phytoplankton, at relatively low temperature and $N_{\mathrm{b}}$. However, most of the annual $P_{\mathrm{b}}$ occurred during summer, coinciding with dominance of nanophytoflagellates and cyanobacteria, high $N_{\mathrm{b}}$ and temperature. These features of the investigated sea areas agree with a potential influence of competition and $K$ of the stratified layer on the $I_{\mathrm{c}}$ and $N_{\mathrm{b}}$ as outlined below.
At all 3 stations, variations of both $r_{\mathrm{c}}$ and $N_{\mathrm{b}}$ were significantly correlated with $P_{\mathrm{b}}$ (Fig. 2). However, the correlation with $r_{c}$ was nearly 3 times higher than with

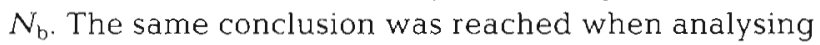
the variance components by a Gauss approximation. This was in accordance with previous studies which observed that the intra-annual variability of $P_{\mathrm{b}}$ is greater than the corresponding dynamics for $N_{\mathrm{b}}$ (Hobbie \& Wright 1979, Wikner \& Hagström 1991, Ducklow \& Shiah 1993). Consequently, most of the intra-annual variability in $P_{\mathrm{b}}$ was due to a variation in $r_{\mathrm{c}}$ potentially controlled by environmental factors such as temperature, substrate quality and competition. Understanding the factors controlling $r_{\mathrm{C}}$ would therefore contribute most to understanding the control of $P_{\mathrm{b}}$ on the intraannual scale.

A positive linear association between $N_{b}$ and temperature was observed in the photic zone at all stations (Fig. 5). However, $N_{b}$ also showed an inverse linear correlation with salinity at both stations in the Bothnian Sea (Fig, 6). Together, temperature and salinity explained $64 \%$ or more of the inter-annual variation in $N_{\mathrm{b}}$ at the Bothnian Sea stations. No similar relationship could be demonstrated for the aphotic zone. A linear association between $N_{b}$ and temperature was reported by Turner \& Borkman (1993) (Buzzards Bay, US East Coast) and Findlay et al. (1991)

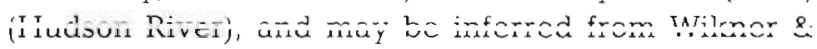
Hagström (1991) (northern Baltic). None of these authors, however, presented an explanation of the cause of this association.

Temperature and salinity are hydrographically connected and combined represent the origin of the water. Low temperature and high salinity are connected with deep water, and the opposite with stratified surface water. The temperature and salinity of the mixed layer thus reflect the extent of stratification of the water column. We assume that stratification is associated with the photic zone $K$ as a consequence of higher plankton productivity in a relatively limited water volume (i.e. the mixed layer) during the warm season. We therefore explain the association between $N_{\mathrm{b}}$, temperature and salinity found in this and other studies with the increased $K$ of the photic zone during stratification. By erosion of the pycnocline and associated mixing with deep water, episodic dilution of both bacterial cells and their energy substrate in the photic zone may also occur (Nômmann et al. 1991). This would also promote the observed association with temperature and salinity. There is little support for direct effects of temperature or salinity on $N_{b}$ as a consequence of direct effect on their physiological activity. Neither could a temperature effect via $r_{c}$ explain the association between temperature and $N_{\mathrm{b}}$ (discussed below). 
We could not find statistical evidence that nutrient limitation was an underlying controlling factor for $N_{\mathrm{b}}$. This was inconsistent with the results of Zweifel et al. (1993). They demonstrated in the same area an increased bacterial growth rate in seawater cultures as the result of added phosphate and a weak negative relationship between phosphate and DOC. From their experiments it was concluded that phosphate was the least available nutrient for the bacteria. If phosphorous limitation had been of marked importance in the present field study a positive, rather than a negative, correlation to salinity would be expected, due to the higher concentrations of inorganic nutrients in deep water (assuming importance of external supply). This was not observed. With our present understanding of the mineral nutrient dynamics in this system it is difficult to present a comprehensive explanation that covers both the response from the bioassay and the intraannual variation in the nutrient tlux.

The association between $P_{\mathrm{b}}$ and temperature observed in this $\left(\mathrm{r}_{\mathrm{p}}=0.602, \mathrm{p}<0.01,0-20 \mathrm{~m}\right.$, all stations pooled) and other studies (Findlay et al. 1991, Ducklow \& Shiah 1993, Hoch \& Kirchman 1993) could therefore mainly be explained by the association between $N_{\mathrm{b}}$ and temperature (Fig. 5). That is, the increase in $P_{\mathrm{b}}$ with temperature was mainly a consequence of higher $N_{\mathrm{b}}$ when water column stratification favoured high plankton production in the photic zone. In contrast, the relationship between $P_{\mathrm{b}}$ and temperature was not clearly associated with the observed temperature effect on $r_{\mathrm{c}}$ (discussed below).

Except during the period of stratification, no clear pattern between $r_{c}$ and temperature could be demonstrated at the community level (Figs. 8 \& 9). At temperatures below $9^{\circ} \mathrm{C}$ the lack of a clear relationship was consistent among the stations, both in the photic and aphotic zone. From the Arrhenius relationship between chemical reactions and temperature, as well as population studies of bacteria, a temperature dependence of the $r_{\mathrm{c}}$ is expected (Stanier et al. 1980). In the case of the coastal station we know that the community occupying the stratified layer during summer has a clearly different species composition (Pinhassi et al. 1997). Thus, a temperature dependence on the community level may be obscured by a succession of species with a different temperature response.

During stratification, a non-linear association between temperature and $r_{\mathrm{c}}$ was observed at the offshore stations. We interpret this association as suggesting that $r_{\mathrm{c}}$ in the stratified photic zone was primarily limited by temperature, other growth factors (e.g. carbon and energy substrate, mineral nutrients) being in sufficiency (Thingstad \& Sakshaug 1990, Ducklow \& Shiah 1993). Thus, the activity of phytoplankton and mineralising grazers in the photic zone appeared to promote a supply of nutrients at a rate sufficient to saturate the bacterial requirement. The reason for the breakdown of this association at the coastal station is unclear.

A correlation between $r_{c}$ and temperature below $12^{\circ} \mathrm{C}$ has been reported from the Delaware estuary, based on sampling surface water at 13 stations during a full annual cycle (Hoch \& Kirchman 1993). This appears to contradict our findings. However, from their Fig. 7 it can be inferred that the variability of $r_{\mathrm{C}}$ in their case also was higher below $9^{\circ} \mathrm{C}$ than above, although a clear relationship in the range 9 to $28^{\circ} \mathrm{C}$ could not be observed. It appears unlikely that a significant relationship between $r_{c}$ and temperature would emerge below $9^{\circ} \mathrm{C}$ in the data set of Hoch \& Kirchman (1993). Thus, the selected temperature interval for regression analysis appears crucial when analysing temperature effects on $r_{\mathrm{c}}$ in field data sets.

The observed decrease in $r_{c}$ at temperatures slightly above the optimum is hard to understand from a physiological point of view. At the community level it should be possible to have a succession of adapted species counteracting limitations of temperature at these low values. A possible explanation for the decrease in $r_{\mathrm{c}}$ above the optimum temperature could be the limitation of $r_{\mathrm{c}}$ by $N_{\mathrm{b}}$ (discussed below), and the temperature dependence of the latter (Figs. 5, 10, 11 \& 12). Thus, the decrease in $r_{c}$ at temperatures above the optimum could have been a result of increased intraor inter-specific competition during late summer.

The only clear association found in the deep water was a linear relationship between $N_{\mathrm{b}}$ and DOC in the aphotic zone of Bothnian Bay (Fig. 7). This required the exclusion of springtime samples, a time when input of sedimenting carbon to the deep water is expected. Given the positive relationship and potential role of the bulk DOC as a substrate, we interpret this association as resulting from carbon or energy limitation of the bacterioplankton (cf. temperature above). Thus, in the aphotic zone of the Bothnian Bay, the bacterial community $K$ appeared limited by the availability of bulk DOC, except during periods of marked supply of seston carbon from the photic zone. No similar relationship could be found in the aphotic zone of the Bothnian Sea.

According to ecological theory, occurrence of competition is expected to result in a negative slope when the per capita growth rate is plotted versus the abundance of a population (Begon et al. 1988). In order to test if indications of competition could be found in our field data set, $r_{\mathrm{c}}$ was plotted versus $N_{\mathrm{b}}$ with the hypothesis that the nature of competition (and resource supply) varied with station, season and depth layer. The different stations showed consistent patterns for the data subsets (Figs. 10-12).

Clear negative relationships between $r_{\mathrm{c}}$ and $N_{\mathrm{b}}$ were observed during winter at both depth layers in the 
Bothnian Bay and Bothnian Sea, suggesting that competition had a marked influence on $I_{\mathrm{c}}$ during this period. In the Bothnian Sea during the cold season low $r_{c}$ was observed above an $N_{\mathrm{b}}$ of approximately $1 \times 10^{9}$ cells $l^{-1}$ at both depth layers. This would be the case if $K$ remained below the in situ $N_{\mathrm{b}}$. Thus, one explanation could be that the supply of limiting resource decreased more rapidly than $N_{\mathrm{b}}$ during autumn, imposing low $r_{c}$ due to competition. Only when $N_{b}$ approached the annual minimum during winter could $r_{c}$ increase (i.e. samples from January to March).

No clear negative trend in the $r_{\mathrm{c}}$ and $N_{\mathrm{b}}$ plots was observed during summer in the photic zone, indicating that competition was not an important factor for controlling $r_{c}$ when resource supply was sufficient (Figs, $10-12$ ). To test this in an alternative way, $P_{\mathrm{b}}$ versus $N_{\mathrm{b}}$ plots were made (data not shown) and analysed using a logistic equation of density-dependent growth with a mortality term added (cf. Begon et al. 1988). This analysis is expected to result in a hyperbolic curve. For all stations in the photic zone during summer, positive slopes were obtained, suggesting that neither density limitation nor mortality was important in controlling $N_{\mathrm{b}}$ compared with the growth rate $\left(r_{\mathrm{c}}\right)$ during the summer period. Our data therefore suggested that competition between bacterioplankton was more or less intense in the pelagic ecosystell, excepi in ille pinviic zunt durilly sumnlle, when increasing resource supply from phytoplankton exceeded the resource demand from the bacterioplankton community. Instead, temperature was the major limiting factor for $r_{\mathrm{c}}$ during the first half of the productive season (cf. above).

The estimates of $r$ and $K$ obtained where competition was significant showed a general trend of low $r$ and high $K$ values in the aphotic zone during the period of marked sedimentation (Table 8). In contrast, winter values suggested high $r$ and low $K$ populations to be dominant, irrespective of the depth interval. These results may be interpreted to mean that sedimentation, corresponding to a high supply of particulate resources in patches promoting a locally high cell density (Alldredge \& Silver 1988), selects for bacterial populations that are primarily competitive by being able to attain a high $K$. In contrast, the winter situation, with dissolved organic matter as the major carbon source and low cell densities, would favour populations that are competitive by being able to exhibit high $r$ on dissolved resources (i.e. bulk DOC). Based on studies of mixed cultures it has been suggested that a trade-off between high $r$ and competitive ability occurs (Kurihara et al. 1990). This should be especially valid for situations with competition in the form of mutual inference (i.e. negative action by metabolites). Our data were thus consistent with the scenario that selection of high- $K$ species occurred in the dense bacterial populations on sedimenting particles, while species showing high $r$ were competitive at low cell densities when dissolved substrates dominated.

Acknowledgements. We are grateful for the efforts made and skill shown by the technical staff at Umea Marine Sciences Centre and the crew of the Coast Guard to collect samples year round. The use of facilities, equipment and ship-time provided by Umeå Marine Sciences Centre was a prerequisite for the performance of this study. Peter Anton, Dept. of Mathematical Statistics, Umea University, provided the basis for the Gauss approximation. Valuable suggestions were also provided by Kjell Leonardsson and Erik Bonsdorff, Dept. of Animal Ecology, Umeå University. This study was made possible by the initiative of the Gulf of Bothnia committee to the 'Gulf of Bothnia Year 1991'. Funding was provided from Umeå University and the Swedish Environmental Protection Agency by grants to $\AA$. H. and J.W.

\section{LITERATURE CITED}

Alldredge AL, Silver M (1988) Characteristics, dynamics and significance of marine snow. Prog Oceanogr 20:41-82

Andersson A, Hajdu S, Haecky P, Kuparinen J, Wikner J (1996) Succession and growth limitation of phytoplankton in the Gulf of Bothnia (Baltic Sea). Mar Biol 126:791-801

Begon M, Harper JL, Townsend CR (1988) Ecology: individuals, populations and communities. Blackwell Scientific Publications, London

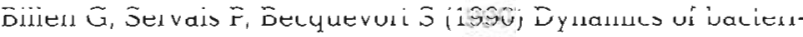
oplankton in oligotrophic and eutrophic aquatic environments: bottom-up or top-down control? Hydrobiologia $207: 37-42$

Brydsten L, Jansson M, Andersson T, Nilsson $\AA$ (1990) Element transport in regulated and non-regulated rivers in northern Sweden. Regul Rivers Res Manag 5:167-176

Cole JJ, Findlay S, Pace ML (1988) Bacterial production in fresh and saltwater ecosystems: a cross systems overview. Mar Ecol Prog Ser 43:1-10

Ducklow HW, Shiah FK (1993) Bacterial production in estuaries. In: Ford TE (ed) Aquatic microbiology. Blackwell Scientific Publications, Oxford, p 261-287

Elmgren R (1984) Trophic dynamics in the enclosed, brackish Baltic Sea. Rapp PV Réun Cons Int Explor Mer 183: $152-169$

Findlay S, Pace ML, Lints D, Cole JJ, Caraco NF, Peierls B (1991) Weak coupling of bacterial and algal production in a heterotrophic ecosystem: the Hudson river estuary. Limnol Oceanogr 36:268-278

Forsgren G, Jansson M (1992) The turnover of river-transported iron, phosphorus and organic carbon in the Öre estuary, northern Sweden. Hydrobiologia 235/236: $585-596$

Forsgren G, Jansson M (1993) Sedimentation of phosphorus in limnetic and estuarine environments in the River Öre system, Northern Sweden. Hydrobiologia 253:233-248

Fuhrman JA, Azam F (1982) Thymidine incorporation as a measure of heterotrophic bacterioplankton production in marine surface waters: evaluation and field results. Mar Biol 66:109-120

Gargas E (1975) A manual for phytoplankton primary production studies in the Baltic. Publ No. 2. Baltic Marine Biologists, Water Quality Institute, Hörsholm 
Grasshoff K, Ehrhardt M, Kremling K (1983) Methods of seawater analysis. Verlag Chemie, Weinheim

GUM (1993) Guide to the expression of uncertainty in measurement. International Organisation for Standardization, Geneva

Hagström $\AA$, Azam F, Wikner J, Andersson A, Rassoulzadegan F (1988) Microbial loop in an oligotrophic pelagic marine environment: possible roles of cyanobacteria and nanoflagellates in the organic fluxes. Mar Ecol Prog Ser 49:171-178

HELCOM (1990) Second periodic assessment of the state of the marine environment of the Baltic Sea, 1984-1988. Baltic Marine Environment Protection Commission, Helsinki Commission. Background document. Baltic Sea Environment Proceedings, No. 35B, Helsinki

Hobbie JE, Wright RT (1979) An assessment of quantitative measurements of aquatic microbes. Arch Hydrobiol Beih Ergebn Limnol 13:85-95

Hobbie JE, Daley R.J, Jasper S (1977) Use of nuclepore filters for counting bacteria by fluorescence microscopy. Appl Environ Microbiol 33:1225-1228

Hoch PM. Kirchman LD (1993) Seasonal and inter-annual variability in bacterial production and biomass in a temperate estuary. Mar Ecol Prog Ser 98:283-295

Joiris C, Billen G, Lancelot C, Daro MH, Mommaerts JP, Bertels A, Bossicart M, Nijs J, Hecq JH (1982) A budget of carbon cycling in the Belgian coastal zone: relative roles of zooplankton, bacterioplankton and benthos in the utilization of primary production. Neth J Sea Res 16:260-275

Kirchman DL, Ducklow HW (1993) Estimating conversion factors for the thymidine and leucine methods for measuring bacterial production. In: Kemp PF, Sherr BF, Sherr EB, Cole JJ (eds) Handbook of methods in aquatic microbial ecology. Lewis Publishers, Boca Raton, p 513-518

Kurihara Y, Shikano S, Toda M (1990) Trade-off between interspecific competitive ability and growth rate in bacteria. Ecology 71:645-650

Larsson U, Hagström $\AA$ (1979) Phytoplankton exudate release as an energy source for the growth of pelagic bacteria. Mar Biol 52:199-206

Larsson U, Hagström $\AA$ (1982) Fractionated phytoplankton primary production, exudate release and bacterial production in a Baltic eutrophication gradient. Mar Biol 67: $57-70$

Mague TH, Friberg E, Hughes DJ, Morris I (1980) Extracellular release of carbon by marine phytoplankton: a physiological approach. Limnol Oceanogr 25:262-279

Nômmann S, Sildam J, Nôges T, Kahru M (1991) Plankton

Editorial responsibility: Frede Thingstad,

Bergen, Norway distribution during coastal upwelling event off Hiiumaa, Baltic Sea: impact of short-term flow field variability. Cont Shelf Res 11:95-108

Pace M (1998) Microbial food webs and aquatic ecosystemsresults from large scale experiments. In: Vaqué $D$ (ed) 6 th European Marine Microbiology Symposium, Sitges, Spain, p 15

Peltzer ET, Fry B, Doering $\mathrm{PH}, \mathrm{McKenna} \mathrm{JH}$, Norrman B, Zweifel UL (1996) A comparison of methods for the measurement of disolved organic carbon in natural waters. Mar Chem 54:85-96

Pettersson C (1992) Properties of humic substances from groundwater and surface waters. Thesis, Dept. of Water and Environmental Studies, Linköping University

Pinhassi J, Zweifel UL, Hagström A (1997) Dominant marine bacterioplankton species found among colony forming bacteria. Appl Environ Microbiol 63:3359-3366

Proctor LM, Fuhrman JA (1990) Viral mortality of marine bacteria and cyanobacteria. Nature 343:60-62

Psenner R, Sommaruga R (1992) Are rapid changes in bacterial biomass caused by shifts from top-down to bottom-up control? Limnol Oceanogr 37:1092-1100

Sokal RR, Rohlf FJ (1995) Biometry. WH Freeman and Company, New York

Stanier R, Adelberg E, Ingraham J (1980) General microbiology. The Macmillan Press Ltd, London

Thingstad TF, Sakshaug E (1990) Control of phytoplankton growth in nutrient recycling ecosystems: theory and terminology. Mar Ecol Prog Ser 63:261-272

Turner JT, Borkman DG (1993) Plankton studies in Buzzards Bay, Massachusetts, USA 1. Hydrography and bacterioplankton, 1987 to 1990. Mar Ecol Prog Ser 100:17-26

White PA, Kalff J, Rasmussen JB, Gasol JM (1991) The effect of temperature and algal biomass on bacterial production and specific growth rate in freshwater and marine habitats. Microb Ecol 21:99-118

Wikner J, Hagström $\AA$ (1991) Annual study of bacterioplankton community dynamics. Limnol Oceanogr 36:1313-1324

Williams P, Yentsch C (1976) An examination of photosynthetic production, excretion of photosynthetic products, and heterotrophic utilization of dissolved organic compounds with reference to results from a coastal subtropical sea. Mar Biol 35:31-40

Wulff F, Rahm L (1990) Nutrient balance in the Baltic. Ambio 19:126-133

Zweifel UL, Norrman B, Hagström Å (1993) Consumption of dissolved organic carbon by marine bacteria and demand for inorganic nutrients. Mar Ecol Prog Ser 101:23-32

Submitted: August 10, 1998; Accepted: June 5, 1999

Proofs received from author(s): December 7, 1999 